\title{
Long-Term Temporal Trends in Agri-Environment and Agricultural Land Use in Ontario, Canada: Transformation, Transition and Significance
}

\author{
Paul G. R. Smith ${ }^{1}$ \\ ${ }^{1}$ Ontario Ministry of Agriculture, Food and Rural Affairs, Guelph, Canada \\ Correspondence: Paul G. R. Smith, Ministry of Agriculture, Food and Rural Affairs, 1 Stone Road West, Guelph, \\ Ontario, Canada. Tel: 151-9826-3573. E-mail: paul.gr.smith@ontario.ca
}

Received: January 27, 2015

Accepted: February 28, 2015

Online Published: April 19, 2015

doi:10.5539/jgg.v7n2p32

URL: http://dx.doi.org/10.5539/jgg.v7n2p32

\begin{abstract}
To help ground agri-environmental policy in evidence, long-term trends in agri-environmental and agricultural land use data in Ontario, Canada (1826-2011, 1921-2011) were identified using correlation and trend detection (Mann-Kendal test) and compared to other parts of Canada and other developed countries. After historic expansion 1826-1931, farm area decreased 1931-2011 by 4 million ha or $44.5 \%$, similar to decreases in eastern Canada, eastern US and other developed countries, but contrasting continued but slowing expansion in western Canada. Ontario crop area varied little 1921-2011, but with large shifts in crop types and production increases. Crop area in eastern Canada was declining or stable, while in western Canada continued increasing. Major changes 1921-2011 included significant declining pasture area (-78.7\%), hay area (-44.9\%) and cattle numbers $(-33.9 \%)$, along with increases in soybean and corn area and in chicken and hog numbers-transforming landscapes, similar to trends in eastern Canada but contrasting western Canada. Two periods of change are identified using principal components analysis, 1921-1970s, a long modernization period (69.1\% of variance) and the $1970 \mathrm{~s}-2011$ period ( $20.1 \%$ of variance), with decreases in cattle numbers, hay and pasture and increases in hogs, chickens, soybeans, corn and wheat. After the 1970s, agri-environmental stewardship increased, and some environmental risks decreased with reduced pesticide use $(-45 \%, 1983-2008)$, phosphorus fertilizer use $(-30.1 \%, 1981-2011)$ and estimated manure volumes $(-42.6 \%, 1976-2011)$. Illustrating the regional diversity of agricultural change, Ontario trends are unique, differing considerably from western Canada, but having some similarities with other eastern provinces, the mid-west and eastern US and many other developed countries. The research emphasizes the need to base agri-environmental policy in sound empirical trend analysis.
\end{abstract}

Keywords: agri-environment, agriculture, farmland, environment, Ontario, Canada

\section{Introduction}

Long-term agri-environmental and agricultural land use trends across the world contribute to regional and global environmental change (Lambin \& Meyfroidt, 2011). Yet aggregate global trends mask vast differences at national and sub-national scales (Ramankutty, Heller, \& Rhemtulla, 2010; Valipour et al. 2015). Studies of centuries-long agri-environmental and land use change are providing important new insights into long-term trends and drivers (Pongratz, Reick, Raddatz, \& Claussen, 2008). Trends can be similar or widely divergent between regions and time periods, with land abandonment, grassland and forest conversion to annual crops or the reverse, and livestock expansion or contraction occurring in different regions and time periods. Understanding trends, past, current and emerging, is important for effective, evidence-based agri-environmental policy. This study identifies trends in Ontario, Canada's most populous and second largest province, and compares these with trends in other provinces and other developed countries.

Agricultural land use change in many developed countries has been marked by transformative major reductions in farm area and cropland area resulting from increases in yields and productivity (Lambin \& Meyfroidt, 2010). The idea of a land use 'transition', especially change increasing forest cover on former farmland, has been suggested for the major changes in Europe, the eastern United States (Rudel et al., 2005; Meyfroidt \& Lambin 2011) and could be applied to Ontario (Larson, Riley, Snell, \& Godschalk 1999; Blancher et al., 2007; Watelet 2009). 
Ontario possesses some of Canada's most productive agricultural soils, some 5.1 million hectares or about $8 \%$ of Canada's farmland, concentrated in southern parts and suitable northern areas (Figure 1; McCuaig \& Manning, 1982; Hofmann, Filoso, \& Schofield, 2005). Farms occupy a significant portion (35.5\%) of the densely populated southern Ontario, while occupying 5.6\% of all of Ontario. Ontario supports a great diversity of agri-products, almost $25 \%$ of Canada's agricultural production, $\mathrm{C} \$ 11.8$ billion in 2012, and about 52,000 farms (2011), about a quarter of all farms in Canada.

Progress in agri-environmental stewardship is evident in most developed countries including Canada (Organization for Economic Cooperation and Development [OECD], 2008, 2013). Ontario's agri-environmental stewardship initiatives in recent decades address soil erosion, water quality, nutrient management, pesticide use and greenhouse gas emissions (Ontario Farm Environment Coalition [OFEC], 1993; Plummer, Speirs, Summer, \& FitzGibbon, 2007; Summers, Plummer, \& FitzGibbon, 2008; Agriculture and Agri-Food Canada, 2009). Sustainability and environmental performance is now becoming a factor in securing and retaining market access.

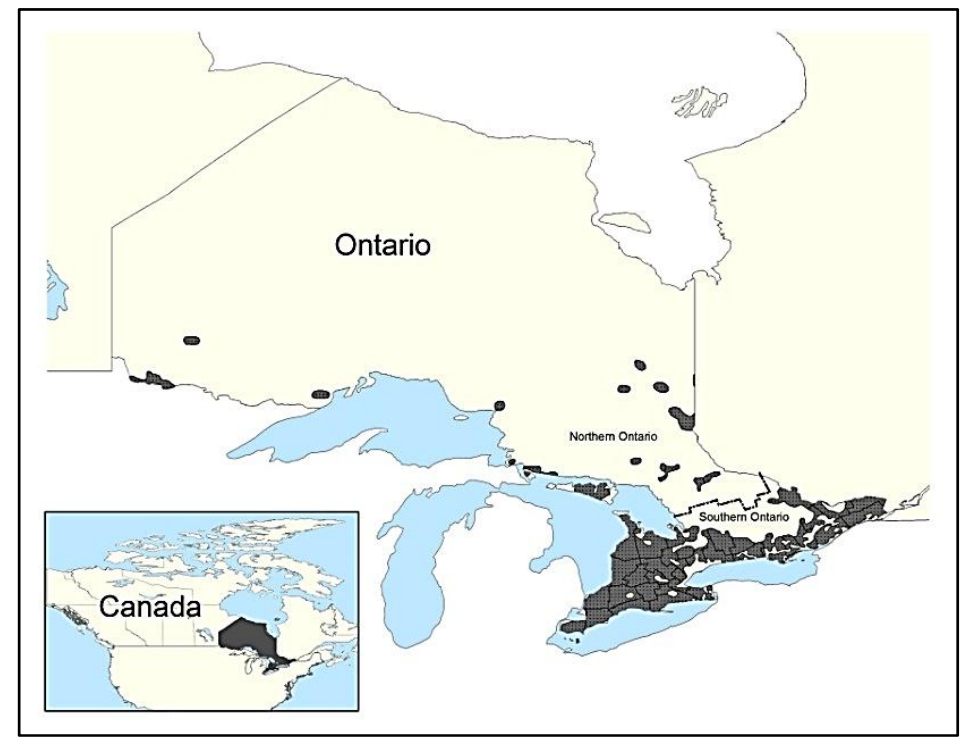

Figure 1. Area where agriculture occurs within Ontario, Canada (boundary between northern and southern Ontario shown)

A number of studies have examined agri-environmental trends at the national level in Canada (e.g. Eilers, MacKay, Graham, \& Lefebvre, 2010) and in developed countries (OECD, 2013). A growing body of studies is revealing long term temporal trends in agriculture across North America at regional, state and provincial scales (Brown, Johnson, Loveland, \& Theobald, 2005; Bucknell \& Pearson, 2006; Wolter, Johnston, \& Niemi, 2006; Hiller, Powell, McCoy, \& Lusk, 2009; Watelet, 2009; Nickerson, Ebel, Borchers, \& Carriazo, 2011). The regions exhibit sometimes consistent, sometimes remarkably differing trends and consequences. Farm area and cropland are decreasing in some regions and stable in others (Brown et al. 2005; Wolter et al. 2006; Hiller et al. 2009; Watelet, 2009; Nickerson et al. 2011), while pasture is decreasing in many regions but increasing in some (Nickerson et al. 2011). Similarly, increases or decreases in livestock numbers differ among regions (Herath, Weersink, \& Carpentier, 2005; Veeman \& Gray, 2010).

Yet agri-environmental trends in Ontario and how these compare with other jurisdictions are not well documented in the primary literature and not well understood by many resource management professionals. Popular generalizations about "industrialization" and "intensification" often prevail over empirical, evidence-based analysis. The decline of agricultural geography research (Morris \& Evans 2004) and in general knowledge of agriculture among the population (Pawlick 2001) has contributed to this dearth of information. Sound, evidence-based agri-environmental policy requires knowledge of the many observed trends of change in agriculture.

Analysis of change at sub-national scales provides important perspectives. In Canada, agri-environmental policy priority setting is often done at the provincial scale. Canada is a federation with considerable provincial legislative powers, a shared jurisdiction for agriculture between federal and provincial levels and many provincial environment-related powers (Rajsic, Ramlal, Fox, \& Brouwer, 2012). 
This study tests for significant agri-environmental and agricultural land use trends in Ontario over many decades (1921-2011) and, where possible, almost two centuries (1826-2011), using a variety of longitudinal, time series data. The intent is to identify what factors changed significantly in the industry (e.g. cropland area, livestock numbers), inputs (e.g. nutrients, pesticides), farm practices (e.g. tillage, nutrient management) and environmental stewardship. Correlation and Mann-Kendall trend tests are used to identify significant temporal trends. The study also examines how changes in Ontario agriculture are different from other parts of Canada and other developing countries using comparable data and studies.

\section{Methods and Data}

\subsection{Agricultural Census Data}

The Census of Agriculture of Canada conducted every five years provides a long-term perspective on agricultural trends and allows assessment of many risks to the environment (Statistics Canada, 2008a, 2012a; Eilers et al., 2010). The information includes farm land use, crops, livestock numbers and agricultural practices. Agri-environmental variables have been added in recent years. Census data was assembled for time periods 1826-2011 (Trant, 1983, Government of Canada, 1935), 1921-2011, 1976-2011 (Statistics Canada, 2007) and other periods for different variables (e.g., Statistics Canada, 2013a). Data for other provinces, where available, were used for comparisons with Ontario. Comparisons are made with studies of other developed nations (e.g. US, OECD) where available. Estimated manure production was calculated from census livestock numbers (excluding horses), for 1976-2011 using detailed coefficients (by species, commodity, age and sex) and methods of Hofmann (2008) and Hofmann and Kemp (2001), and for 1921-2011 using more generalized coefficients (by species).

\subsection{Pesticide and Fertilizer Data}

A survey of pesticide use in Ontario is conducted every five years, estimating the amount of active ingredient applied and environmental risk (Gallivan, Surgeoner, \& Kovach, 2001; McGee, Berges, \& Beaton, 2010). Annual fertilizer sales data is drawn from reports from Agriculture and Agri-food Canada (Korol, 2002) and Statistics Canada (2013b). The data is reported as tonnes of nutrient per year, nitrogen and phosphate equivalents, after conversion of different types of fertilizer to comparable measures.

\subsection{Agri-Environmental Stewardship Data}

Under Ontario's Environmental Farm Plan (EFP) program, individual farmers attend a workshop, prepare Environmental Farm Plans identifying actions needed, many have these reviewed by a third party and then go on to implement the actions identified. Statistics have been collected since 1993 on farmers' workshop participation and third-party review of plans. Since 2005, statistics have been kept on best management practice projects completed. Several evaluations of the EFP are drawn on for context (Plummer et al., 2007; Summers et al., 2008; Agriculture and Agri-Food Canada, 2009; Prairie Research Associates, 2011; Woyzbun, 2012).

\subsection{Statistical Analysis}

Data presented in this paper are time series at a provincial scale. The census time periods covered are generally 1921-2011 or 1976-2011, with some longer periods, 1826-2011, or shorter, such as 1991-2011, depending on the data available. The pesticide survey data are a time series 1983-2008 and fertilizer data from 1951-2011.

Data analysis methods are primarily longitudinal, temporal trend analysis using correlation with Mann-Kendall test statistics (Yue, Pilon, \& Cavadias, 2002), to identify statistically significant trends. Often used in environmental and land use monitoring, the Mann-Kendall non-parametric test is appropriate for monotonic trend detection for sequential temporal data, not relying on any assumed distribution, accommodating missing data, irregular intervals, and uses only the relative magnitude of values (Chandler \& Scott, 2011). The MAKESENS Excel add-on was used for calculations (Salmi et al., 2002). Principal components analysis is used to identify the main overarching temporal change gradients in census data 1921-2011.

\section{Results and Discussion}

Ontario has a long history of agriculture including that undertaken by indigenous peoples before European colonization. Ontario's agriculture changed dramatically since the beginning of European colonization, beginning around 1780. The extent of land area of Ontario farms 1826-2011 is shown in Figure 2, illustrating growth of clearing of land by European settlers throughout the $19^{\text {th }}$ century.

Table 1 summarizes changes in key farm characteristics and crops over the time period 1921-2011 and the two segments 1921-1976 and 1976-2011. A number of variables appear only in the 1976-2011 period when statistics were collected on those variables. Trends in Ontario are also compared with those in eastern and western Canada 
in Table 1.

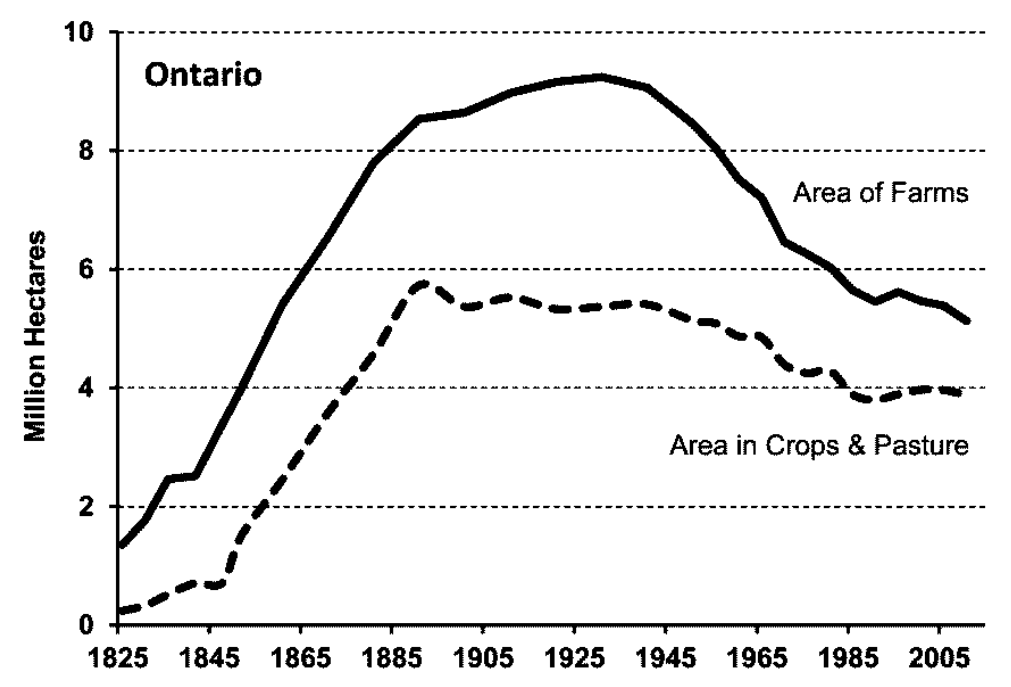

Figure 2. Change in area of farms and area of cropland and improved pasture in Ontario 1826-2011

\subsection{Total Area of Farms}

The total area of farms includes cropland, pasture, woodland, wetland, farmstead (including buildings and dwellings) and all other lands owned, leased or controlled. The extent of the total land area of Ontario farms expanded 1826-1931 and then declined as illustrated in Figure 2. The percent of Ontario land area occupied by farms declined from a peak of $10.1 \%$ of Ontario in 1931 (60.7\% of southern Ontario) to 5.6\% of Ontario in 2011 (35.5\% of southern Ontario). The total area of Ontario farms decreased by four million hectares, or $44 \%$, over the period 1921-2011 (Table 1). This land use transition is similar to trends in total farm area in most eastern provinces in Canada (Figure 3a; Table 1) and many parts of the developed world (Wolter et al., 2006; Nickerson et al., 2011; OECD, 2013). But in Canada's western provinces, total farm area did not peak until late in the 20th century due in part to later European settlement, primarily in the early 20th century (Figure 3a, Table 1). A similar east-west contrast in timing of growth and contraction of farmland has been observed in the US (Waisanen \& Bliss 2002; Nickerson et al., 2011), given the similar colonial history.

The drop in total farm area is the product of a number of drivers including growing productivity, abandonment of marginal agricultural land, efficiency, urban encroachment, growth of rural residential properties and other factors (Veeman \& Gray, 2010; McCuaig \& Manning, 1982). The decrease in overall farmland area is primarily composed of decreases in pasture, woodland and wetlands in farm ownership, while cropland area remained relatively stable. Land clearing for agriculture peaked around 1920 when forest cover in southern Ontario was about 10.6\% (Larson et al. 1999; Blancher et al., 2007), although Figure 2 suggests the peak was earlier, in 1891 (also see Watelet, 2009).

\subsection{Total Area of Cropland}

Cropland refers to farmland planted with annual or perennial crops, including grains, oilseeds, hay, fruits, vegetables and many other crops, but excluding pasture. The area of land in crops declined from a peak in 1891 (Figure 2) but has been remarkably similar over the period 1921-2011 (Figure 3b and Table 1), fluctuating between 3.9 and 3.2 million hectares. On a percentage basis, cropland increased from $41.5 \%$ to $70.5 \%$ of total farm area over the period 1921-2011, as other land types decreased. Since 1978, many public policy instruments have been put in place to protect farmland from urban encroachment including land use planning policy, farmland property tax incentives, Greenbelt legislation and growth plans (Pond, 2009; Government of Ontario, 1998, 2005a, 2005b, 2006).

The relative stability in Ontario cropland extent is similar to eastern Canadian provinces, at least since 1981 (Figure 3b, Table 1) and the mid-west US (Nickerson et al. 2011). This stability contrasts the late 20th century increases in cropland in western provinces like Alberta, Saskatchewan and Manitoba (Figure 3b, Table 1), primarily due to reduced summer fallow (Eilers et al., 2010), a practice more prevalent in western Canada historically. It also differs from the decreases in cropland in many eastern US states (Ramankutty et al., 2010; 
Waisanen \& Bliss 2002) and other developed countries (OECD 2013). At the same time, crop and livestock productivity on roughly the same land base has grown enormously in Ontario and elsewhere (Morrison et al., 2000; Veeman \& Gray, 2010).

Table 1. Temporal change in farm characteristics and crops in Ontario and comparisons to western and eastern Canada

\begin{tabular}{|c|c|c|c|c|c|c|c|}
\hline \multirow[t]{2}{*}{ Variable } & \multicolumn{5}{|c|}{ Ontario } & \multirow{2}{*}{$\begin{array}{l}\text { Western } \\
\text { Canada }^{c} \\
\text { Correlation } \\
\text { with Year }^{\mathrm{a}}\end{array}$} & \multirow{2}{*}{$\begin{array}{l}\text { Eastern } \\
\text { Canada }^{\mathrm{c}} \\
\text { Correlation } \\
\text { with Year }^{\mathrm{a}}\end{array}$} \\
\hline & $\begin{array}{l}\text { 1921-2011 } \\
\text { Percent } \\
\text { Change }\end{array}$ & $\begin{array}{l}\text { 1921-1976 } \\
\text { Percent } \\
\text { Change }\end{array}$ & $\begin{array}{l}\text { 1976-2011 } \\
\text { Percent } \\
\text { Change }\end{array}$ & $\begin{array}{l}\text { Correlation } \\
\text { with Year }\end{array}$ & $\begin{array}{l}\text { Significance } \\
\text { level of Mann- } \\
\text { Kendall test }^{\mathrm{b}}\end{array}$ & & \\
\hline Number of farms & $-73.8 \%$ & $-55.2 \%$ & $-41.5 \%$ & -1.000 & $* * *$ & -0.988 & -0.997 \\
\hline Total area of farms & $-44.0 \%$ & $-31.6 \%$ & $-18.1 \%$ & -0.988 & $* * *$ & 0.844 & -0.976 \\
\hline Average Farm Size & $113.4 \%$ & $52.5 \%$ & $40.0 \%$ & 1.000 & $* * *$ & 1.000 & 0.991 \\
\hline Percent of Land Owned & & & $-6.6 \%$ & -0.810 & $* *$ & -0.357 & -0.881 \\
\hline Land in Crops (area) & $-4.8 \%$ & $-7.6 \%$ & $3.0 \%$ & -0.082 & n.s. & 0.985 & -0.709 \\
\hline Pasture, unimproved (area) & $-72.0 \%$ & $-55.5 \%$ & $-37.2 \%$ & -0.854 & $* *$ & & \\
\hline Pasture, improved (area) & $-78.7 \%$ & $-39.6 \%$ & $-64.7 \%$ & -0.906 & $* * *$ & 0.952 & -1.000 \\
\hline $\begin{array}{l}\text { All Other Land on farms (primarily } \\
\text { woodlands \& wetlands) }\end{array}$ & $-65.3 \%$ & $-46.4 \%$ & $-35.3 \%$ & -0.904 & $* *$ & -0.023 & -0.976 \\
\hline Hay (area) & $-44.9 \%$ & $-17.5 \%$ & $-27.1 \%$ & -0.921 & $* * *$ & 0.857 & -0.857 \\
\hline Wheat (area) & $75.9 \%$ & $-22.8 \%$ & $127.9 \%$ & 0.300 & n.s. & 0.368 & 0.565 \\
\hline Corn, grain (area) & $861.9 \%$ & $647.9 \%$ & $28.6 \%$ & 0.885 & $* * *$ & 0.747 & 0.921 \\
\hline Corn, silage (area) & & & $-68.6 \%$ & -0.905 & $* *$ & 0.595 & -0.310 \\
\hline Soybeans (area) & & & $552.3 \%$ & 0.989 & $* * *$ & 0.738 & 1.000 \\
\hline Oats (area) & $-97.5 \%$ & $-80.9 \%$ & $-87.0 \%$ & -0.979 & $* * *$ & -0.868 & -0.947 \\
\hline Barley (area) & $-69.2 \%$ & $-10.1 \%$ & $-65.8 \%$ & -0.053 & n.s. & 0.579 & 0.626 \\
\hline Potatoes (area) & $-77.4 \%$ & $-72.4 \%$ & $-18.2 \%$ & -0.876 & $* * *$ & 0.447 & -0.300 \\
\hline Tree Fruits (area) & $-84.6 \%$ & $-68.0 \%$ & $-51.9 \%$ & -0.994 & $* * *$ & -0.929 & -0.991 \\
\hline Berries \& grapes (area) & & & $-15.1 \%$ & -0.524 & n.s. & 1.000 & 1.000 \\
\hline Vegetables, field (area) & $575.0 \%$ & $645.6 \%$ & $-9.5 \%$ & 0.909 & $* * *$ & 0.750 & 0.953 \\
\hline Greenhouses (area, 1981-2011) & & & $240.9 \%$ & 0.964 & $* *$ & 1.000 & 0.929 \\
\hline
\end{tabular}

a Spearman correlation of variable with year in longest time series available

${ }^{\mathrm{b}}$ Statistical significance level of Mann-Kendall test reported: $\mathrm{n} . \mathrm{s} .=\mathrm{P}>.05 ; *=\mathrm{P} \leq .05 ; * *=\mathrm{P} \leq .01 ; * * *=\mathrm{P}$ $\leq .001 ; * * * *=\mathrm{P} \leq .0001$

${ }^{c}$ Western Canada includes Manitoba, Saskatchewan, Alberta and British Columbia; Eastern Canada includes Quebec, New Brunswick, Nova Scotia, Prince Edward Island and, for time series 1976-2011, Newfoundland and Labrador. 

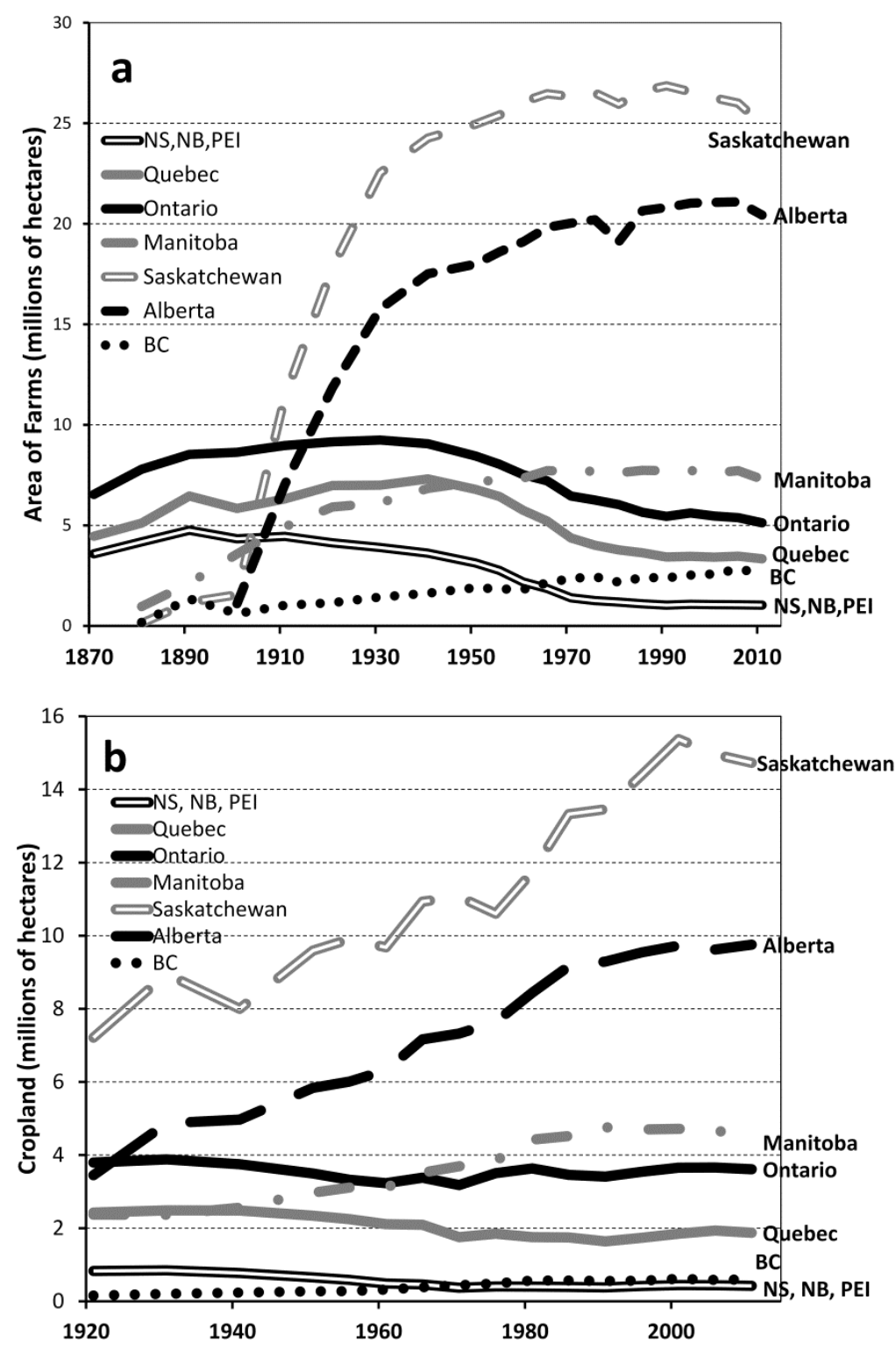

Figure 3. Change in area of farms in different Canadian provinces 1870-2011 (a) and area of cropland 1921-2011 (b) (NS = Nova Scotia, NB=New Brunswick, PEI=Prince Edward Island)

\subsection{Area of Woodlands, Wetlands and Non-Production Lands on Farms}

The amount of farm area in woodlands, wetlands and other non-production lands decreased by $65.3 \%$ or 1.6 million hectares between 1921 and 2011 and dropped from 26.5\% to 16.4\% of total farm area (Table 1). A similar decreasing trend exists in eastern Canada, while in western Canada the proportion remained stable (Table 1). However, the total area of forest in southern Ontario has increased primarily through reversion of former agricultural lands through natural succession (Larson et al., 1999; Blancher et al., 2007). So some forests, wetlands and former pastures appear to have shifted ownership to the growing number of non-farm landowners, consistent with the shift in rural populations (Milburn, 2011). The re-growth of forest cover, primarily in central, eastern and northern regions of Ontario (Larson et al., 1999; Blancher et al., 2007; Watelet, 2009), is a land use transition occurring across eastern North America and most developed countries (Rudel et al., 2005; Nickerson et al., 2011). However, in the last number of years with higher crop commodity prices, anecdotal evidence suggests some hedgerows, forests and small wetlands may be undergoing conversion to annual crops.

Historically, wetlands were drained for agricultural and public health objectives in Ontario and across developed nations. Over $72 \%$ of southern Ontario's wetlands have been lost since European settlement (Schulte-Hosteddea, 
Walters, Powell, \& Shrubsole, 2007; Ducks Unlimited, 2010). A series of public policy initiatives in the 1980s and 1990s sought to stop the loss of wetlands in Ontario (Loftus, Smardon, \& Potter, 2004; Schulte-Hosteddea et al., 2007). 3.5\% wetland loss occurred in 1982-2002 (Duck Unlimited, 2010), but the data cannot indicate the effectiveness of policies later in that period. On-farm wetland restoration is now more common with technical and incentive support, and abandonment of less productive farmland has also led to wetland recovery (Loftus et al., 2004).

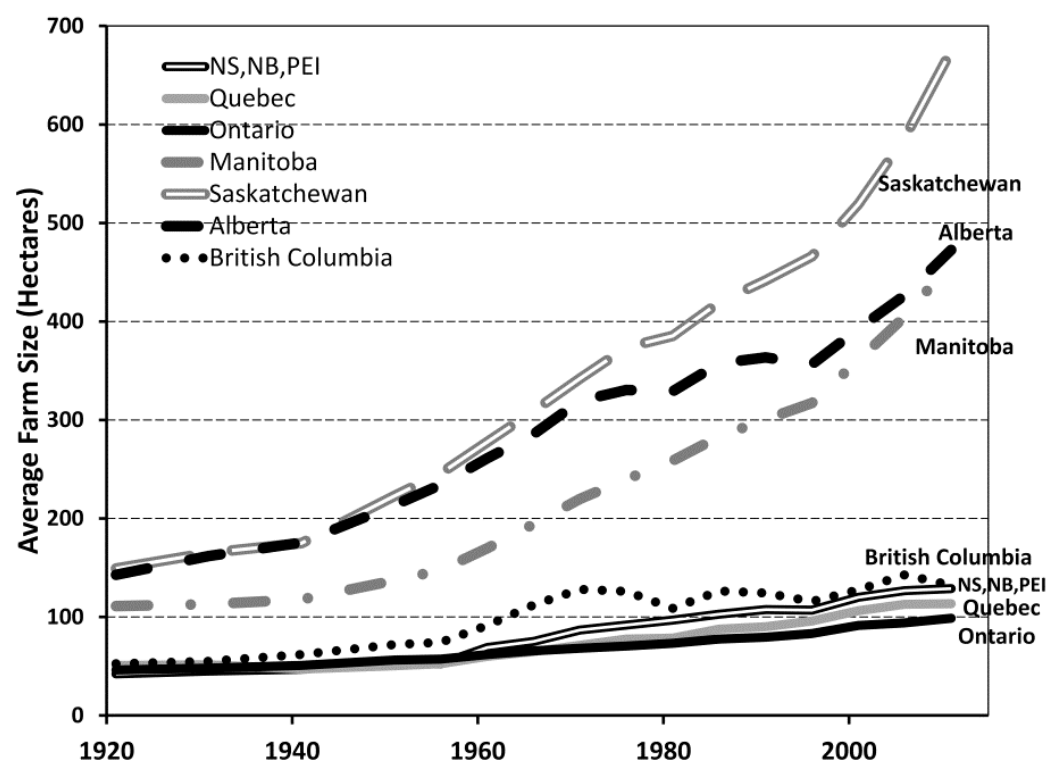

Figure 4. Change in average farm size in different Canadian provinces 1921-2011 (NS = Nova Scotia, NB=New Brunswick, PEI=Prince Edward Island)

\subsection{Farm Size and Structure}

The total numbers of farms declined over many decades and average farm size (in area) has increased (Table 1) with increasing efficiency of production, a well-known phenomenon in all economic sectors in developed countries (OECD, 2013). The average farm size in Ontario in 2011 was 98.7 hectares, a change of $114 \%$ since 1921, but remains the smallest in Canada, with the exception of Newfoundland (Figure 4). The percent change in average Ontario farm size 1921-2011 is also the lowest among Canadian provinces, with a national percent increase of 292\% (Table 1; Figure 4). The rate of increase in farm size has been greatest in Saskatchewan, Alberta and Manitoba, due to geography, crop types and change in technology. Ontario average farm size is also small relative to other jurisdictions such as the US and Australia (Statistics Canada, 2008), but similar to farms in the eastern US and the UK (Eastwood, Lipton, \& Newell, 2010). While average farm size has only doubled in Ontario, averages are simplistic and can be misleading, not representing the full nature of change. The vast majority of farms (98\%) continue to be farm family owned and operated.

A trend of specialization in commodities occurred since the nineteenth century, away from the low input-low output mixed farming of many decades past, similar to most developed countries (Veeman \& Gray, 2010). Interestingly, in Ontario and eastern Canada both the number of farms and total farm area decreased 1921-2011, while in western Canada the number of farms decreased but total farm area increased (Table 1). Farms in 2011 also have a higher percentage of annual cropland, lower percentage of forages, wetland and woodland. The diversity of crops grown in Ontario decreased 1976-2011, with the total percent of cropland covered by the top four crops (corn, soy, wheat, hay) increasing from $71.6 \%$ in 1976 to $90.3 \%$ in 2011.

\subsection{Crops: Grains, Oilseeds and Forages}

The types of crops grown in Ontario have shifted dramatically over time (Table 1, Figure 5a) with changing end uses, consumer preferences, trade, technology, plant breeding and other factors. The transformation of Ontario cropland after 1960 is particularly focused on expansion of grain corn and soybeans (Joseph \& Keddie, 1981; Keddie, 1983; Small, 1999; Keddie \& Wandel, 2001) and contraction of forages, pasture and mixed farming. New varieties for colder climates, other genetic improvements, markets and production methods explain the 
changes (Veeman \& Gray 2010). The rapid modification in crops during 1960s to 1980s, along with unsuitable management practices, led to action to mitigate soil erosion, degradation and water quality impacts (Senate of Canada, 1984; Stonehouse \& Bohl, 1990).

The area planted to grain corn more than tripled 1961-81, and levelled off 1981-2011 (Figure 5a; also see Joseph \& Keddie, 1981, Keddie, 1983; Hamel \& Dorff 2014). In Canada, corn is grown primarily in Ontario (61.7\% of area in 2011) and Quebec. The expansion of corn was greatest in Ontario, but in Quebec and Manitoba corn area increased as well, and grain corn area spiked in almost all provinces in 2011 due to high prices (Table 1). Yield of corn also increased dramatically during that time period (Veeman \& Gray 2010; Hamel \& Dorff 2014). In contrast, area of corn grown for silage or livestock feed decreased in area significantly during 1976-2011 in Ontario (Table 1), but increased in several western provinces after 1990 (Table 1).
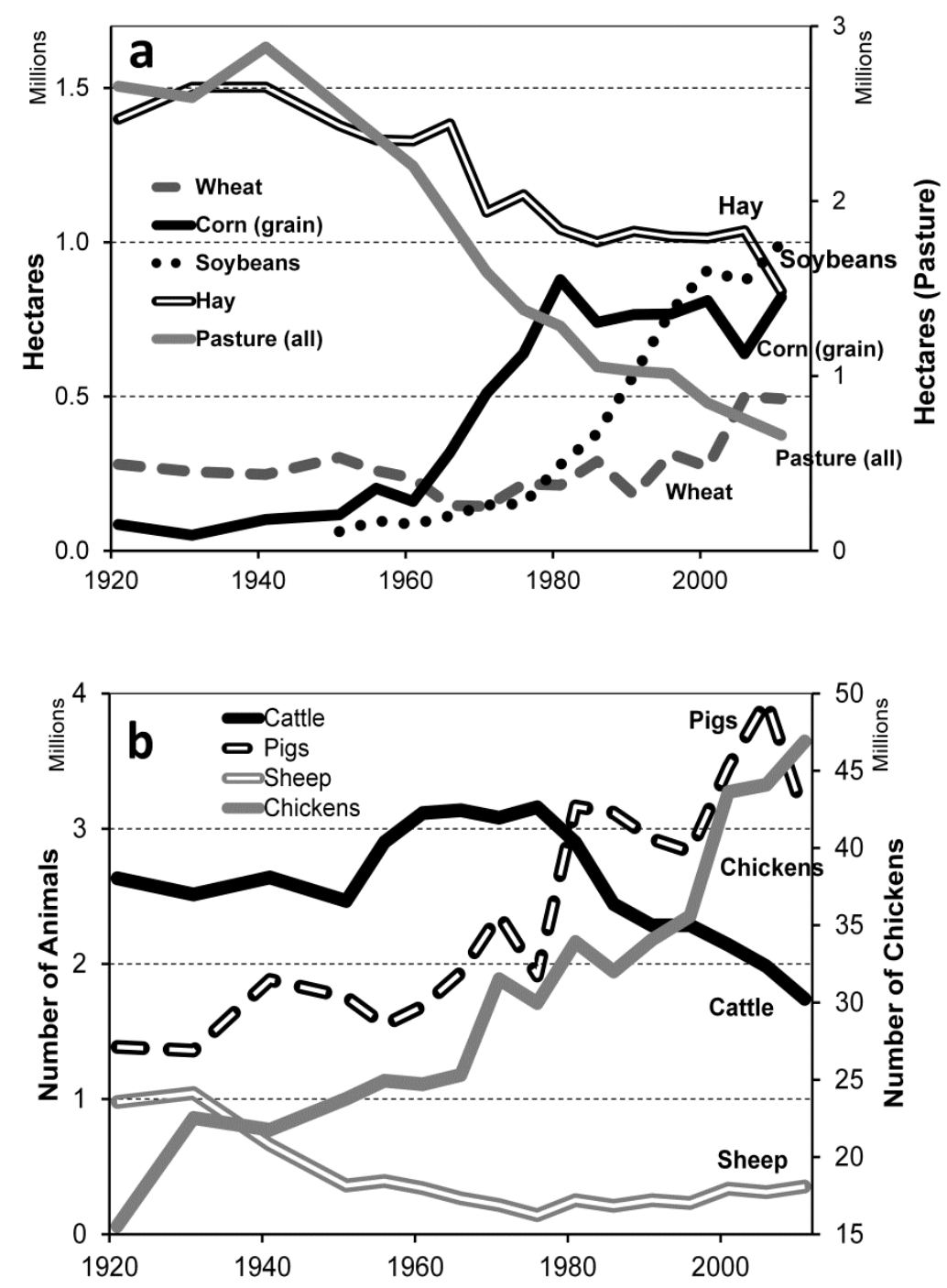

Figure 5. Changes in area planted in different crops (a) and livestock numbers (b) in Ontario, 1921-2011

Wheat underwent a resurgence over 1976-2011, more than doubling in area, after a decline in the 1960s and 70s (Figure 5a). Winter wheat is by far the predominant type of wheat grown in Ontario (90.4\% of area in 2011). Wheat area declined in western Canada after 1990 due to changes in markets and policy, especially transportation policy (Doan, Paddock, \& Dyer, 2006).

Perhaps the biggest change was the meteoric rise of soybeans in 1976-2011 to be the field crop with greatest extent at almost one million hectares (23.8\% of cropland), more than either corn or hay (Figure 5a), due to newer 
cold-hardy cultivars and other reasons (Morrison et al., 2000; Keddie \& Wandel, 2001; Hume \& Pearson, 2011). Ontario had $62.3 \%$ of Canada's area in soybeans in 2011, with Quebec and Manitoba each with about $17 \%$ and both also showing increases over the last 10-20 years (Table 1). This parallels growth in soybean acreage in the US and South America (Hiller et al., 2009). Corn, soybeans and wheat have become a standard recommended rotation of crops for cash crop production (Government of Ontario, 2009), preferably with additional crops in the rotation to benefit soil health. However, it is thought that corn-soybean is the most common crop rotation, not ideal for soil health.

Hay and pasture have seen significant long-term declines in area (Table 1, Figure 5a), a major transformative trend and seems likely to continue. The decrease in area of hay undermines the use of forages within a crop rotation to build soil health, and is resulting in declining organic matter in many Ontario soils (Eliers et al., 2010). The decrease in hay and pasture is linked to the reduced numbers of cattle, east to west shifts of cattle production within Canada, and changes in production systems (Venman \& Gray, 2010; Agriculture and Agri-Food Canada, 1997a). In contrast to Ontario and eastern Canada, pasture and hay area grew considerably during the late $20^{\text {th }}$ century in western Canada (Alberta, Saskatchewan and, to a lesser extent, Manitoba; Table 1). Nevertheless, hay and pasture acreage also decreased somewhat in western Canada after 2006. Two-thirds of developed countries had decreases in pasture 1998-2010 (OECD, 2013) as did most regions of the US (Nickerson et al. 2011).The decreasing amount of pasture and hay in Ontario coupled with re-growth of forest on abandoned farmland contributed to decreases in grassland birds and wildlife that expanded with the historic expansion of agriculture (McCracken, 2005).

\subsection{Fruits and Vegetables}

Field production of vegetables and fruit occurs primarily in specific regions within Ontario and occupies a modest area of land compared to grains, oilseeds and forages. Acreage of field vegetable production climbed steadily 1921-2001 and subsequently declined some 2001-2011 (Table 1). Similar growth trends and recent declines occurred in many provinces (Table 1). While potato production grew, potato acreage shrank significantly during 1921-76, especially 1930-50, and remained relatively stable 1976-2011. Regardless of area planted, yield and production for most vegetables was far higher in 2011 than historically (Dorff 2014).

The largest fruit crops in Ontario are apples and grapes, but the moderate climate of southern Ontario allows cultivation of many tree fruits as well as grapes and small fruits (Small, 1999; Statistics Canada, 2012b; Dorff 2014). Tree fruit production grew dramatically, but tree fruit acreages declined significantly 1921-41, and continued a slower decline to 2011 (Table 1), similar to a Canada-wide pattern (Table 1; Small, 1999; Dorff 2014). Challenges of climatic variability, specialization, trade issues, processing capacity and other factors led to the concentration of tree fruits in the most favorable regions (Van Vliet, Macintosh, \& Hoffman, 1979; Krueger, 2000; Dorff 2014). Berry and grape acreages declined between 1986 and 1991 in part due to international competition, but gradually increased acreages 1991-2011. Many other provinces saw significant increases in berry and grape area (Table 1; also see Dorff 2014).

Greenhouse production, for vegetables and flowers, is also highly regional, occupying a relatively small land area in southwestern Ontario. Growth has been dramatic in the last 25 years in Canada and Ontario, Ontario accounting for 54.2\% of greenhouse area in Canada in 2011 (Table 1; Small, 1999; Papadopoulos \& Gosselin, 2007; Statistics Canada 2012b; Dorff 2014).

\subsection{Livestock}

The changes in livestock numbers from 1921 to 2011 are shown in Figure 5b and Table 2 also indicates change in the percentage of farms reporting livestock by species, as well as comparisons with other provinces. Consistent with specialization and productivity growth, numbers of animals per farm have increased and the percentage of farms with livestock have decreased for all species discussed (Table 2), as they have in other provinces and most developed countries (Thornton, 2010; Veeman \& Gray, 2010). Significant east-west livestock production shifts occurred in Canada (Veeman and Gray 2010) and similar east-west as well as northeast-south regional livestock shifts also occurred in the United States (Herath et al. 2005). Specialization and spatial concentration of larger numbers of animals also occurred in Ontario and Canada raising concerns about manure management (Beaulieu \& Bédard, 2003; Hofmann, 2008).

Manure management issues, including nutrients and pathogens, greenhouse gas production, and odours are primary environmental concerns for all livestock species (Thornton, 2010). Manure management is addressed in section 3.12. Ruminant production is a significant source of greenhouse gas emissions in agriculture, especially methane. Nevertheless, forage production for ruminants builds soil organic matter, carbon and prevents erosion. Modelling shows declining beef and dairy numbers in Ontario reduced methane production in recent decades 
(Eilers et al., 2010; Environment Canada, 2013).

Cattle numbers reached a maximum in Ontario in 1976 (Figure 5b), following a post-World War 2 expansion, and then declined. In western Canada, the cattle expansion continued until the early 2000s, while cattle numbers declined throughout eastern Canada (Table 2). This is a transformative trend driving other changes such as increasing area of annual crops.

Table 2. Temporal change in livestock on Ontario farms and comparisons to western and eastern Canada

\begin{tabular}{|c|c|c|c|c|c|c|c|}
\hline \multirow[b]{3}{*}{ Variable } & \multicolumn{5}{|c|}{ Ontario } & \multirow{3}{*}{$\begin{array}{l}\text { Western } \\
\text { Canada }^{\mathrm{c}} \\
\text { Correlation } \\
\text { with Year }^{\mathrm{a}}\end{array}$} & \multirow{3}{*}{$\begin{array}{l}\text { Eastern } \\
\text { Canada }^{c} \\
\text { Correlation } \\
\text { with Year }^{\mathrm{a}}\end{array}$} \\
\hline & $\begin{array}{l}\text { 1921-2011 } \\
\text { Percent } \\
\text { Change }\end{array}$ & $\begin{array}{l}\text { 1921-1976 } \\
\text { Percent } \\
\text { Change }\end{array}$ & $\begin{array}{l}\text { 1976-2011 } \\
\text { Percent } \\
\text { Change }\end{array}$ & $\begin{array}{l}\text { Correlation } \\
\text { with } \text { Year }^{\mathrm{a}}\end{array}$ & $\begin{array}{l}\text { Significance } \\
\text { level of } \\
\text { Mann-Kendall } \\
\text { test }^{\mathrm{b}}\end{array}$ & & \\
\hline & & & & & & & \\
\hline Cattle (number) & $-33.9 \%$ & $20.0 \%$ & $-44.9 \%$ & -0.585 & $*$ & 0.929 & -0.862 \\
\hline $\begin{array}{l}\text { Percent of farms with } \\
\text { cattle }\end{array}$ & $\begin{array}{r}-45.2 \% \\
(1941-2011)\end{array}$ & $\begin{array}{r}-20.3 \\
(1941-76)\end{array}$ & $-24.9 \%$ & -1.000 & $* * *$ & -0.776 & -1.000 \\
\hline Dairy Cows (number) & & & $-52.2 \%$ & -1.000 & $* * *$ & -0.929 & -1.000 \\
\hline $\begin{array}{l}\text { Percent of farms with } \\
\text { dairy cows }\end{array}$ & & & $-16.7 \%$ & -1.000 & $* * *$ & -1.000 & -1.000 \\
\hline Beef Cows (number) & & & $-44.5 \%$ & -0.595 & n.s. & 0.524 & 0.024 \\
\hline $\begin{array}{l}\text { Percent of farms with } \\
\text { beef cows }\end{array}$ & & & $-14.8 \%$ & -0.786 & $*$ & -0.440 & -0.772 \\
\hline Pigs (number) & $122.8 \%$ & $38.1 \%$ & $61.4 \%$ & 0.891 & $* * *$ & 0.809 & 0.959 \\
\hline $\begin{array}{l}\text { Percent of farms with } \\
\text { pigs }\end{array}$ & $-65.2 \%$ & $-47.1 \%$ & $-16.1 \%$ & -0.988 & $* * *$ & -0.947 & -0.997 \\
\hline Sheep (number) & $-64.0 \%$ & $-85.6 \%$ & $150.5 \%$ & -0.571 & $*$ & -0.691 & -0.575 \\
\hline $\begin{array}{l}\text { Percent of farms with } \\
\text { sheep }\end{array}$ & $-9.9 \%$ & $-14.2 \%$ & $3.2 \%$ & -0.562 & $*$ & 0.079 & -0.838 \\
\hline Horses (number) & $-87.0 \%$ & $-88.4 \%$ & $11.9 \%$ & -0.603 & $*$ & -0.545 & -0.931 \\
\hline $\begin{array}{l}\text { Percent of farms with } \\
\text { horses }\end{array}$ & $-65.4 \%$ & $-65.7 \%$ & $0.4 \%$ & -0.818 & $* * *$ & -0.896 & -0.935 \\
\hline Chickens (number) & $202.1 \%$ & $93.0 \%$ & $56.5 \%$ & 0.988 & $* * *$ & 0.926 & 0.973 \\
\hline $\begin{array}{l}\text { Percent of farms with } \\
\text { chickens }\end{array}$ & $\begin{array}{r}-55.0 \% \\
(1951-2011)\end{array}$ & $\begin{array}{r}-45.7 \% \\
(1951-76)\end{array}$ & $-9.2 \%$ & -0.934 & $* * *$ & -0.984 & -0.890 \\
\hline
\end{tabular}

${ }^{a}$ Spearman correlation of variable with year in longest time series available

${ }^{\mathrm{b}}$ Statistical significance level of Mann-Kendall test reported: $\mathrm{n} . \mathrm{s} .=\mathrm{P}>.05 ; *=\mathrm{P} \leq .05 ; * *=\mathrm{P} \leq .01 ; * * *=\mathrm{P}$ $\leq .001 ; * * * *=\mathrm{P} \leq .0001$.

${ }^{\mathrm{c}}$ Western Canada includes Manitoba, Saskatchewan, Alberta and British Columbia; Eastern Canada includes Quebec, New Brunswick, Nova Scotia, Prince Edward Island and, for time series 1976-2011, Newfoundland and Labrador.

Beef cattle numbers have declined in Ontario since 1976 while expanding in western Canada in the late $20^{\text {th }}$ century, with cyclic variation (Table 2, Figure 5b), and broader declines across Canada in the 2000s due in part to the Bovine Spongiform Encephalopathy (BSE) crisis. The average size of each animal has also increased significantly, for example a 34\% increase 1980-2003 (Thornton, 2010; Veeman \& Gray, 2010). Beef production consists of cow-calf, backgrounder and feedlot operations, with Ontario operations being significantly smaller than in western Canada and US. Beef production has changed in response to changes in national and international production, processing methods, consumer preferences (Thornton, 2010), increased production in western Canada due to reduction in grain supports, land and feed prices, and trade (Doan et al. 2006; Veeman \& Gray, 2010).

Significant decreases in the numbers of dairy cows occurred after 1976 (Table 2, Figure 5b) due to increases in milk production per animal (Sargeant et al., 1998) and decreased per capita consumption of dairy products. Similar decreases in dairy cattle occurred across Canada (Table 2) and the developed world (Thornton, 2010). 
Ontario and Quebec are the primary dairy producing provinces. Greenhouse gas production by the dairy industry decreased 1981-2006 due primarily to decreased animal numbers (Eilers et al., 2010).

An enormous rise in chicken production occurred across Canada (Table 2, Figure 5b), especially in Ontario, Quebec and British Columbia, and around the world (Thornton, 2010), and reflects major changes in consumer preferences (Kearney, 2010; Lynn \& Robbins, 1986). Confined feeding production methods increased significantly in Ontario, Canada and all developed countries (Thornton, 2010).

Hog numbers grew to an historic peak in 2006 in Ontario and declined significantly in 2007-2011 due to poor market conditions (Figure 5b; also see Brisson 2014). The hog industry is cyclical and affected by monetary exchange rate, cost of production, country-of-origin labelling, and US economic situation. Across Canada, especially in Quebec, Ontario and Manitoba - the provinces with the most hogs, hog production increased since the 1960s, but declined post-2006 across Canada (also see Brisson 2014). The growth, geographic concentration, odour, high phosphorous manure, confined feeding production methods, and large numbers of hogs per farm (Hofmann, 2008; Hofmann \& Kemp, 2001) led to public concerns in Ontario and across North America, which contributed to the development of Ontario's Nutrient Management Act (Ferreyra, de Loe \& Kreutzwiser, 2008).

Sheep numbers grew 1976-2011 in Ontario and Canada, after an earlier Canada-wide decline 1921-72 (Table 2, Figure $5 b$ ). The more recent increases also occurred in Quebec and the prairie provinces. Consumer preferences and growth in ethnic markets have increased lamb consumption which is expected to continue growth (Thornton, 2010).

Historical, agricultural use of horses in Ontario and Canada declined dramatically with mechanization in early to mid- twentieth century (Table 2), from a maximum in 1910 in Ontario. But in recent decades recreational use of horses, especially in the urban fringe, has expanded across the western world (Elgåker, 2012). The agricultural census does not reflect horses used for sport and recreational use. Estimates of the total population of horses in Ontario in 2006 ranged from 230,000 to 380,000 , meaning $58-74 \%$ of horses were not on farms (Wilton \& Caldwell, 2009 and Evans, 2011 respectively). Demand for hay for recreational horses helped keep Ontario acreage of hay relatively high in recent decades until 2011 (Figure 5a).

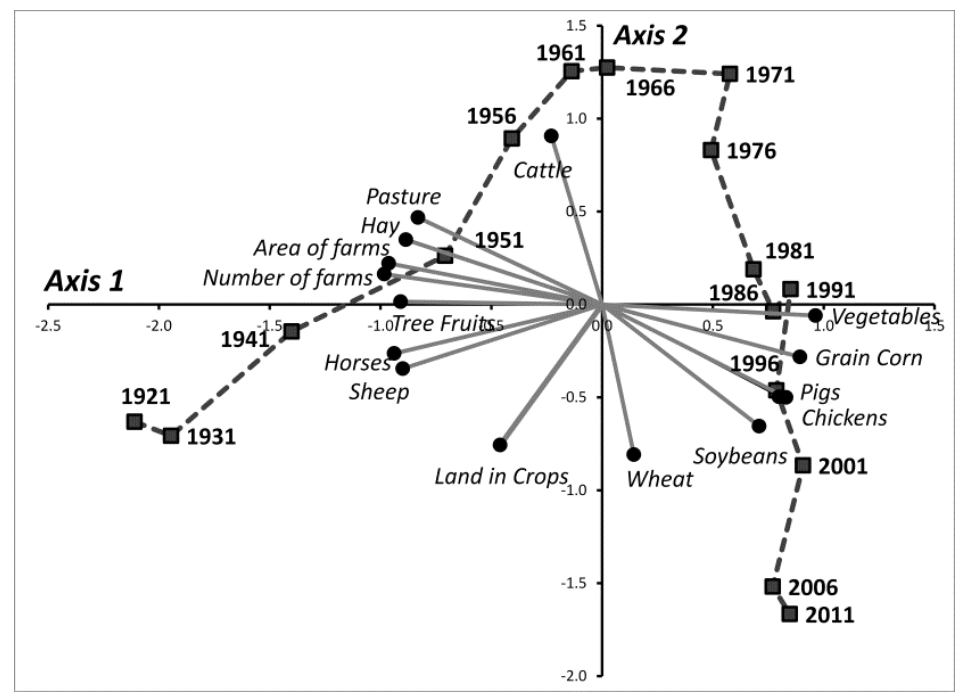

Figure 6. Biplot of principal components analysis of selected census variables for the years 1921-2011, scores of each census year on the two axes are shown as are the loadings of each census variable on each axis

\subsection{Major Components of Long-Term Change}

Given the complexity of the changes described above, principal components analysis was used to summarize the dominant trends in agricultural change 1921 to 2011, as represented by two principal components of a subset of census variables shown in a biplot in Figure 5. Axis 1 represents the long term change $(69.1 \%$ of variance) of reduced numbers and total area of farms, decreasing acreage of forages, decreasing numbers of horses, and expansion of grain corn, soybeans and field vegetables (high loadings on those variables). This trend is a fairly typical trajectory for agricultural change in many developed countries in the early to mid-20th century. This could be regarded as a modernization or "intensification" gradient. Axis 2 summarizes the change since the 
1970s through 2011 (20.1\% of variance), when cattle numbers declined, hog and chicken numbers grew, soybean acreage expanded dramatically, and wheat acreage expanded again after a long previous decline. Both gradients illustrate the long-term transformation of Ontario agriculture.

\subsection{Tillage Practices}

Soil conservation concerns since the 1980s, led to promotion of no-till and conservation tillage methods in recent decades (Stonehouse \& Bohl, 1990; Yates, Bailey, \& Schwindt, 2006). Reduced tillage approaches leave a larger proportion of biomass on the land surface, reduce soil erosion, increase soil biodiversity and build soil health (Derpsch, Friedrich, Kassam, \& Hongwen, 2010). Some research suggests an unintended consequence of no-till may be increases in runoff of dissolved phosphorous, especially in the changing conditions of the 2000s in the Great Lakes (Joosse \& Baker, 2011). Reduced tillage has been thought to increase soil organic matter, but research suggests reduced tillage changes the distribution of organic matter in the soil profile rather than increasing it overall in most soils (Yang et al., 2013), especially in humid climates such as Ontario.

The reported growth in no-till and reduced tillage practices 1991-2011 and the decrease in conventional tillage in Ontario is shown in Figure 7a and Table 3 (see also Eilers et al., 2010). Some questions exist about whether reported tillage practices in the census reflect actual practices (see Uri, 1999; Lobb et al., 2007). No till practices are more difficult to implement in corn and this lowers long-term no-till adoption rates within a rotation. Widespread anecdotal reports suggest increases in tillage, especially fall tillage, in recent years, leading to concerns about soil health.

Current reported Ontario levels of no-till (33.1\% of cropland in 2011), reduced tillage (29.8\% in 2011) and "most of residue incorporated into soil" tillage (37.1\% in 2011) are similar to the levels in the US (Derpsch et al., 2010), although different terminology make direct comparisons difficult. Zero till and reduced tillage practices are generally most widespread in the drier prairie provinces, especially Saskatchewan and Alberta, dominated by cereals and pulses, intermediate in BC, Manitoba and Ontario and lowest in eastern Canadian provinces (Table 3; Statistics Canada, 2008, 2012). Adoption of conservation tillage and no-till is reportedly highest in South America, intermediate in North America and lower in Europe and Asia (Derpsch et al., 2010).

\subsection{Pesticide Use}

Overall pesticide use - insecticide, herbicide and fungicide — and associated environmental risk gradually decreased in Ontario agriculture over the period from 1983 to 2003 and increased some in 2008, with overall use decreasing by more than 45\% 1983-2008 (Figure 7b, Table 3). Insecticides (and other pesticides) showed the most consistent and significant decline. Herbicide use declined 1983-2003 and increased 2003-2008. Fungicide use has remained relatively similar 1983-2008. The overall decrease resulted from targeted extension and incentives for integrated pest management, changes in production, increasing cost of pesticides, pest resistant varieties and other factors (Gallivan et al., 2001; Government of Ontario, 2003b; McGee et al., 2010).

Large decreases in insecticide use in field crops occurred over the 25 -year period, as broad-spectrum pest control products were gradually replaced by more target-specific technology, with low amounts of active ingredient used per acre. On the other hand, glyphosate use increased in several crops, primarily due to the development of glyphosate resistant varieties, and this in turn led to reduced use of metolachlor. Concerns about pesticide toxicity and water quality impacts resulted in initiatives to reduce pesticide impacts (Government of Ontario, 2003b).

Pesticide detections in Ontario municipal water supplies declined 1986-2006, primarily due to decreases in pesticides banned in the 1970s (McInnis, 2010). Total pesticide use in Quebec was relatively unchanged 1992-2009 but environmental and health risk indicators were lower by $39.5 \%$ and $35.6 \%$ in 2009 , respectively, compared to 1997 (Gouvernement du Québec, 2012). Data on trends in pesticide use in other provinces are not available (Environment Canada, 2011). In the United States, pesticide use in agriculture (active ingredient) increased in the 1960s through the 1980s and subsequently stabilized in aggregate, with increasing herbicide use, decreasing insecticide use and static fungicide use in recent decades (Grube et al., 2011; Osteen \& Fernandez-Cornejoa, 2013). Between 1992 and 2010, many developed countries increased pesticide use, while many others reduced use and Europe reduced use by 14.2\% (OECD, 2013). 

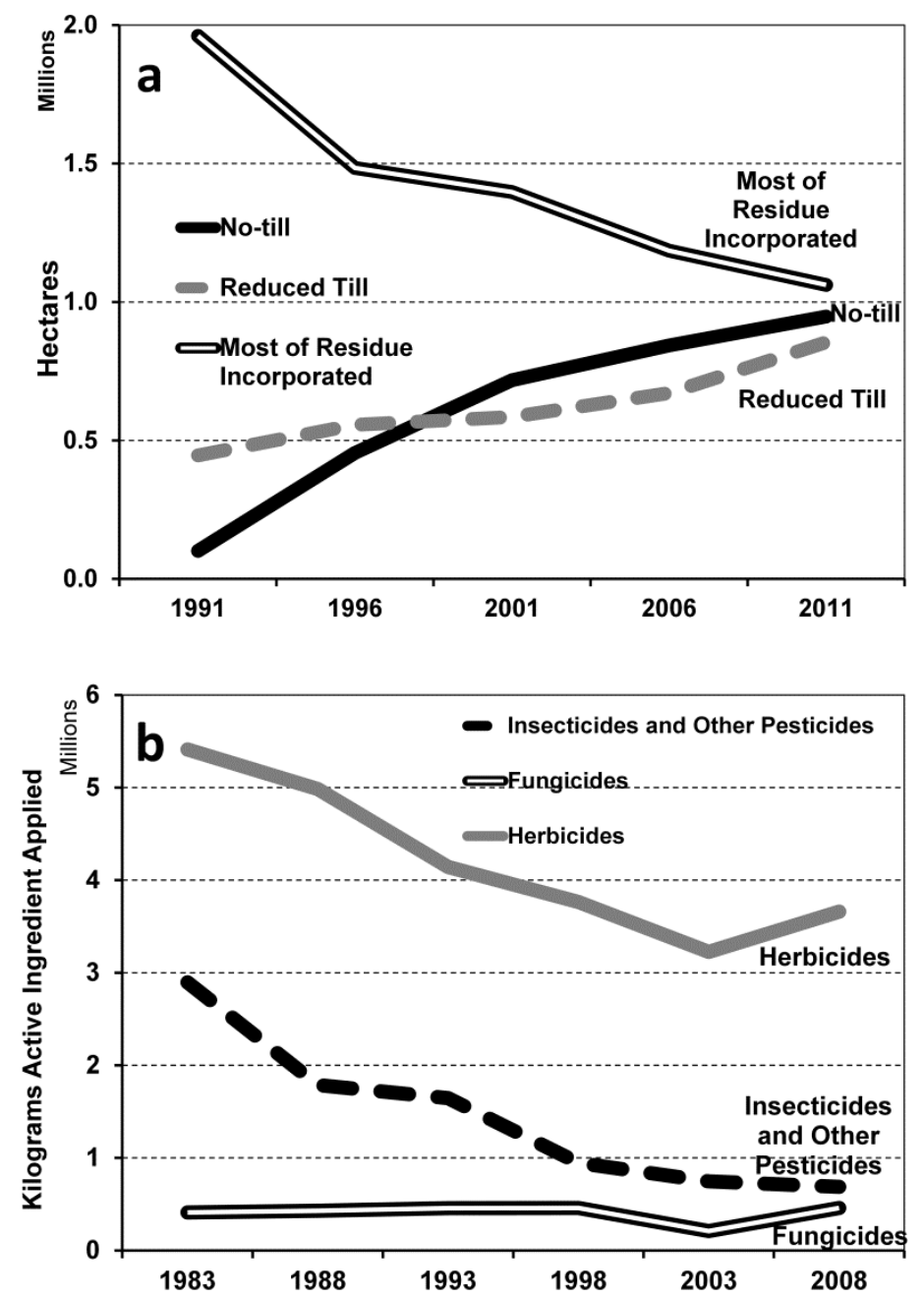

Figure 7. Reported tillage on cropland in Ontario, 1981-2011 (a) and pesticides used on Ontario crops 1983-2008

(b)

\subsection{Fertilizer Use}

Fertilizer nitrogen and phosphorus have potential to impact surface and ground water quality, through runoff and leaching, and greenhouse gas emissions (Eilers et al., 2010). Great Lakes water quality programs have focused on reducing nutrients, especially phosphorus, from agriculture including both fertilizer and manure (Shear, 2006; Joosse \& Baker, 2011; Dolan \& Chapra, 2012). Nitrous oxide emissions resulting from nitrogen fertilizer use has been the focus of climate change mitigation concerns (Venterea et al., 2012).

Fertilizer sales in Ontario grew during the 1950s to peaks in the 1970s and early 1980s - peaks in 1979 for phosphorus and 1985 for nitrogen - declining in 1980s-early 2000s and apparently increasing in the last few years (Figure 8a, Table 3). The decline 1981-2000 was most significant in phosphorus use, less so for nitrogen (Huffman et al., 2006; MacDonald \& Bennett, 2009; Bruulsma, Mullen, O’Halloran, \& Warncke, 2011). Soil test phosphorus levels have decreased as well (Bruulsma et al., 2011). The downward trend in fertilizer use 1980-2000 in Ontario echoes decreases in eastern Canadian provinces but contrasts continued increases in western provinces, with some levelling off in recent years (Table 3; also see Dorff \& Beaulieu, 2014).

A statistically significant decrease occurred in the percentage of Ontario farms using fertilizer, similar to western and eastern Canada (Figure $8 \mathrm{~b}$ and Table 3). No significant trend in the percent of Ontario farmland where commercial fertilizers were reported 1981-2011, while the percent of land receiving fertilizers increased 1991-2011 in western Canada (Alberta, Saskatchewan) and was decreasing or relatively unchanged in other provinces (Table 3; Statistics Canada, 2008b, 2013b). 
Table 3. Temporal changes in farm practices in Ontario with comparisons to western and eastern Canada

\begin{tabular}{|c|c|c|c|c|c|c|}
\hline \multirow[b]{2}{*}{ Variable } & \multicolumn{4}{|c|}{ Ontario } & \multirow{2}{*}{$\begin{array}{l}\text { Western } \\
\text { Canada }^{c} \\
\text { Correlation } \\
\text { with Year }\end{array}$} & \multirow{2}{*}{$\begin{array}{l}\text { Eastern } \\
\text { Canada }^{\mathrm{c}} \\
\text { Correlation } \\
\text { with Year }^{\mathrm{a}}\end{array}$} \\
\hline & $\begin{array}{l}\text { Time } \\
\text { Period }\end{array}$ & $\begin{array}{l}\text { Percent } \\
\text { Change }\end{array}$ & $\begin{array}{l}\text { Correlation } \\
\text { with Year }\end{array}$ & $\begin{array}{l}\text { Significance } \\
\text { level of Mann-- } \\
\text { Kendall test }^{\text {b }}\end{array}$ & & \\
\hline No-till (area) & $1991-2011$ & $836.1 \%$ & 1.000 & $*$ & 1.000 & 1.000 \\
\hline Reduced Till (area) & 1991-2011 & $91.6 \%$ & 1.000 & $*$ & -0.700 & 1.000 \\
\hline Most of Residue Incorporated (area) & $1991-2011$ & $-45.9 \%$ & -1.000 & $*$ & -1.000 & -1.000 \\
\hline Herbicide use (kg active ingredient) & $1983-2008$ & $-32.37 \%$ & -0.943 & $*$ & & \\
\hline Fungicide use (kg active ingredient) & $1983-2008$ & $11.50 \%$ & -0.314 & n.s. & & \\
\hline $\begin{array}{l}\text { Insecticide and Other Pesticide use ( } \mathrm{kg} \\
\text { active ingredient) }\end{array}$ & $1983-2008$ & $-76.25 \%$ & -1.000 & $* *$ & & \\
\hline $\begin{array}{l}\text { Fertilizer use (percent of hectares } \\
\text { receiving) }\end{array}$ & $1981-2011$ & $-6.5 \%$ & -0.786 & n.s. & 0.643 & -0.964 \\
\hline $\begin{array}{l}\text { Fertilizer use (percent of farms reporting } \\
\text { use) }\end{array}$ & $1981-2011$ & $-11.2 \%$ & -0.964 & $* *$ & -0.750 & -0.964 \\
\hline Fertilizer sales, Nitrogen (tonnes) & $1954-1980$ & $824.3 \%$ & 0.967 & $* * *$ & 0.961 & 0.992 \\
\hline Fertilizer sales, Nitrogen (tonnes) & 1981-2011 & $3.1 \%$ & -0.426 & $* *$ & 0.813 & 0.672 \\
\hline Fertilizer sales, Phosphate (tonnes $\mathrm{P}_{2} \mathrm{O}_{5}$ ) & $1954-1980$ & $159.2 \%$ & 0.985 & $* * *$ & 0.913 & 0.900 \\
\hline Fertilizer sales, Phosphate (tonnes $\mathrm{P}_{2} \mathrm{O}_{5}$ ) & $1981-2011$ & $-30.1 \%$ & -0.791 & $* * *$ & 0.612 & -0.935 \\
\hline Manure volume produced & 1976-2011 & $-42.6 \%$ & -1.000 & $* * *$ & 0.929 & -0.838 \\
\hline
\end{tabular}

${ }^{\mathrm{a}}$ Spearman correlation coefficient

${ }^{\mathrm{b}}$ Statistical significance level of Mann-Kendall test reported: n.s. $=\mathrm{P}>.05 ; *=\mathrm{P} \leq .05 ; * *=\mathrm{P} \leq .01 ; * * *=\mathrm{P}$ $\leq .001 ; * * * *=\mathrm{P} \leq .0001$.

${ }^{c}$ Western Canada includes Manitoba, Saskatchewan, Alberta and British Columbia; Eastern Canada includes Quebec, New Brunswick, Nova Scotia, Prince Edward Island and, for time series 1976-2011, Newfoundland and Labrador.

Aggregate fertilizer use in the United States showed increases 1960s-1970s in phosphorus and levelling off 1980-2010, and increases for nitrogen 1960s to 1990s, levelling off in the 2000s (USDA Economic Research Service, 2012). In Europe 1992-2009, use of fertilizer decreased and indicators of nitrogen and phosphorus balance surpluses decreased by $40.4 \%$ and $78.6 \%$ respectively (OECD, 2013).

The environmental impact of the trend in use of fertilizer is a complex amalgam of rate of application, fertilizer types used, application method, area of application, manure application, yield, removal by crops, residual nutrients present in soil, and other site specific factors (Bruulsma et al., 2011; OECD, 2008). Crop removal and increased yield have been major factors in reducing phosphorus surpluses (MacDonald \& Bennett, 2009). Impacts on Great Lakes water quality lessened between the 1980s and early 2000s, as many indicators for water quality improved (Shear, 2006; Dolan \& Chapra, 2012). Yet the dynamics of nutrients in the Great Lakes became more complex due to influences like alien dressinid mussels, mobilization of phosphorus in sediment and climate change (Hecky et al., 2004; Chapra \& Dolan, 2012). Recent increases in dissolved phosphorus and harmful algae blooms led to increased focus on phosphorus again. 

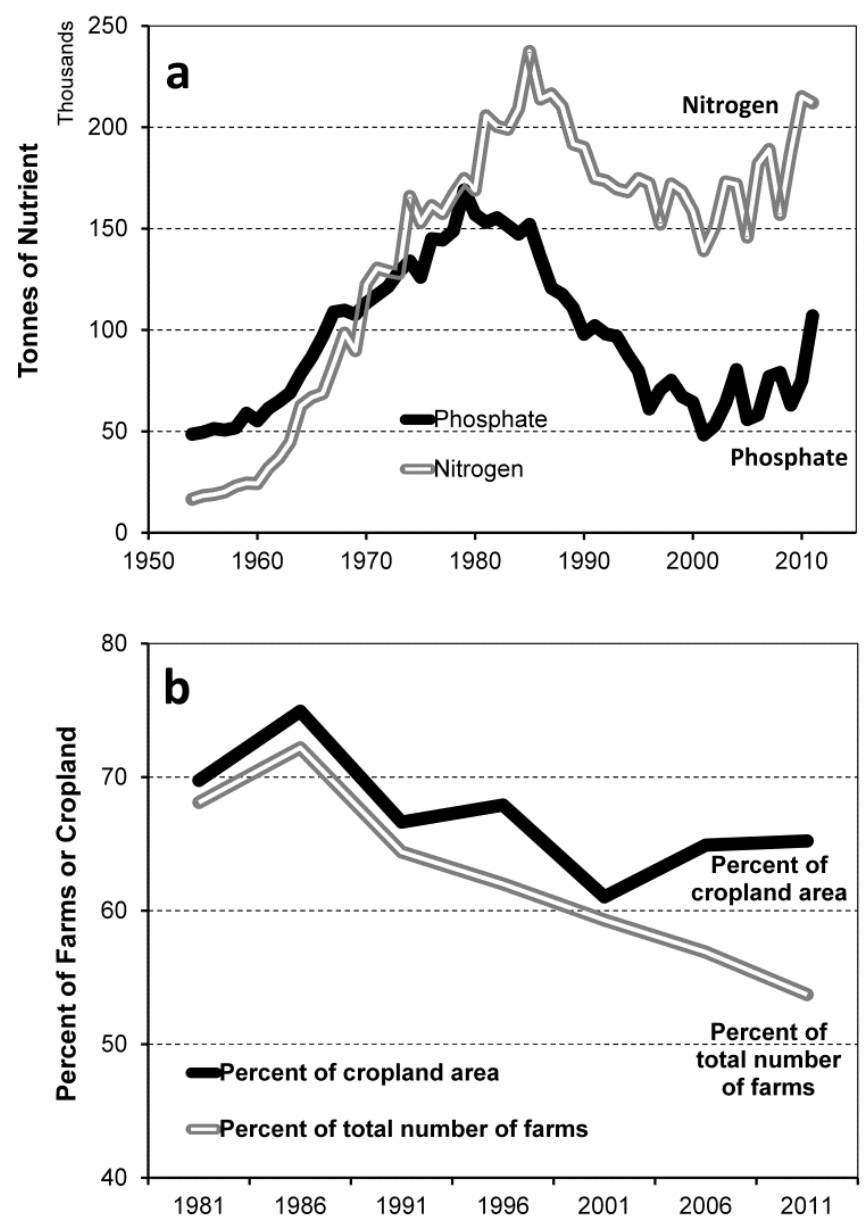

Figure 8. Fertilizer sales 1954-2010 (a) and on-farm use 1981-2011 (b) in Ontario

Emphasis on nutrient management by the Canadian and Ontario governments and municipalities grew in the 1990s (Eilers et al., 2010; Government of Ontario, 2003a, 2002; Caldwell, 2001), as did the price of fertilizer (Statistics Canada, 2008a). Indicators for environmental risks from nitrogen appear relatively stable in Ontario, while the indicator for environmental risk from phosphorus has been decreasing (Eilers et al., 2010). Estimates of Ontario soil-related greenhouse gas emissions, primarily nitrous oxide, were relatively stable 1990-2011 (Environment Canada, 2013) or declining 1981-2006 (Eilers et al., 2010), depending on the time frame measured. However, very recent increases 2006-2011, in annual crop area and fertilizer use could indicate some increases, depending on nutrient use efficiency.

\subsection{Manure Management}

Manure can have a number of impacts including nutrient contributions to water quality issues, pathogen introductions in surface and ground water and air quality impacts due to odour and ammonia (Unc \& Goss, 2004; Ferreyra et al., 2008; Eilers et al., 2010). The Walkerton drinking water tragedy and beach closures in certain regions of Ontario have focused public concern about manure management (Ferreyra et al., 2008; Unc \& Goss, 2004). Ontario's Nutrient Management Act was developed to ensure sound management of manure and other nutrients to avoid risks to the environment (Government of Ontario, 2002). In 2013, an estimated 4,054 livestock farms were required to meet regulatory standards under the Nutrient Management Act, including most large livestock farms and expanding livestock farms.

Consistent with trends in livestock numbers (Figure 5b), the estimated amount of manure produced in Ontario (see section 2.1) appears to have peaked in 1976 and declined subsequently (Table 3). Estimated manure production from dairy and beef farms declined by $52.2 \%$ and $45.3 \%$ respectively $1976-2011$ due to lower animal numbers. While estimated manure produced on pork, sheep and poultry farms increased by $60.0 \%, 150.5 \%$ and 
$35.3 \%$ respectively, the volumes are considerably lower than beef and dairy due to smaller size of each animal and the numbers of animals. Manure calculations for other provinces show decreases in eastern Canada and increases in western Canada (Table 3), reflecting the changes in livestock within Canada discussed earlier in section 3.7 (Table 2).

A number of studies have used livestock data to model trends in potential environmental risks from nitrogen, phosphorus, pathogens and ammonia (Eilers et al., 2010). Nitrogen and phosphorus risk indicators are covered in section 3.11. A national indicator of risk due to coliform bacteria showed an ongoing risk 1981-2006 in certain watersheds in southwestern Ontario from concentration of livestock and local soil characteristics as well as in certain watersheds in Alberta, Quebec and Manitoba (Hofmann, 2008; Hofmann \& Kemp, 2001; Eilers et al., 2010). A shift from solid manure to liquid manure management systems in recent decades, especially in pork and dairy production, has also led to larger volumes of liquid requiring management (Eilers et al., 2010; Dorff \& Beaulieu, 2014). Ontario's Nutrient Management Act, Environmental Farm Plan and other initiatives led to significant investment after 2005 in nutrient management practices, especially in areas with concentrations of livestock (Wozybun, 2012).

In the 2006 and 2011 censuses, the first data on manure application showed the percent of Ontario cropland receiving manure was $23.1 \%$ and $21.8 \%$ in 2006 and 2011 respectively. Manure is an important soil amendment for annual cropping to maintain and build soil organic matter and soil health (Government of Ontario, 2009). With increasing regional concentration of livestock, manure is not available in all areas of annual crops, a concern for long-term soil health. For example, in 2006 the extremes in the percentage of cropland receiving manure in different Ontario counties were from $43.0 \%$ (Waterloo, south central Ontario) to $3.6 \%$ (Essex, southwest Ontario).

\subsection{Water Use}

Due to a temperate, humid climate, agriculture in Ontario is primarily rain-fed with irrigation primarily for specific field crops, horticultural and specialty crops and in specific regions (de Loë, 2005; Beaulieu et al. 2007; Agriculture and Agri-Food Canada, 2011; Valipour, 2013, 2014; Valipour et al. 2015). Only 1.2\% of Ontario cropland was irrigated in 2010 ( $42,000 \mathrm{ha}$ ) and only $2.4 \%$ of the irrigation water in Canada was used in Ontario in 2010 (Statistics Canada 2011). Total agricultural water use in Ontario was estimated at 174,130 $\mathrm{m}^{3}$ and $3.6 \%$ of agricultural water use in Canada in 2001 (Beaulieu et al. 2007). De Loë (2005) found water use increased 1991-2001 for all agricultural sectors except fruit. $\operatorname{OECD}(2008,2010,2013)$ also reported increased use of water 1990-2003.

Ontario's temperate, humid climate also means artificial drainage has played a significant role in agriculture since the $19^{\text {th }}$ century (Kelly 1975). An estimated 1.75 million hectares, or about $48 \%$ of cropland in 2011 , have tile drainage installed. Both tile drainage and drainage ditches form part of the drainage system. Artificial drainage can have significant environmental impacts, which are often soil type and landscape dependent (Loftus et al. 2004; Blann et al. 2009; Madramootoo et al. 2007).

Management of drainage has evolved over the years with broader water management, wetlands and fisheries habitat becoming more prominent factors (Walters \& Shrubsole 2005; also see section 3.3). Specific best management practices for reducing nutrient and sediment loss from drainage have been developed and tested in Ontario (e.g. Drury et al. 2009) and promoted in recent agri-environmental programs. Installation of new tile drainage and drainage ditches has decreased in recent decades and replacement and maintenance projects have become more prevalent. However, recent higher prices for grains and oilseeds appear to have led to an increase in tile drainage installation or replacement of old tile systems.

\subsection{Agri-Environmental Stewardship}

Environmental stewardship in agriculture has a long history in Ontario (Summers et al., 2008) and Canada, which parallels similar work in the United States and Europe. In the 1990s, farm organizations developed the Ontario Environmental Farm Plan (EFP) to address environmental concerns in agriculture, in cooperation with government (Ontario Farm Environment Coalition 1993; Plummer et al., 2007; Ferreyra et al., 2008; Summers et al., 2008; Agriculture and Agri-Food Canada, 2009). The Environmental Farm Plan is both a risk assessment tool and an educational process that helps farmers identify best environmental practices. Participants with third party reviewed plans have been eligible for funding to implement their plans. 


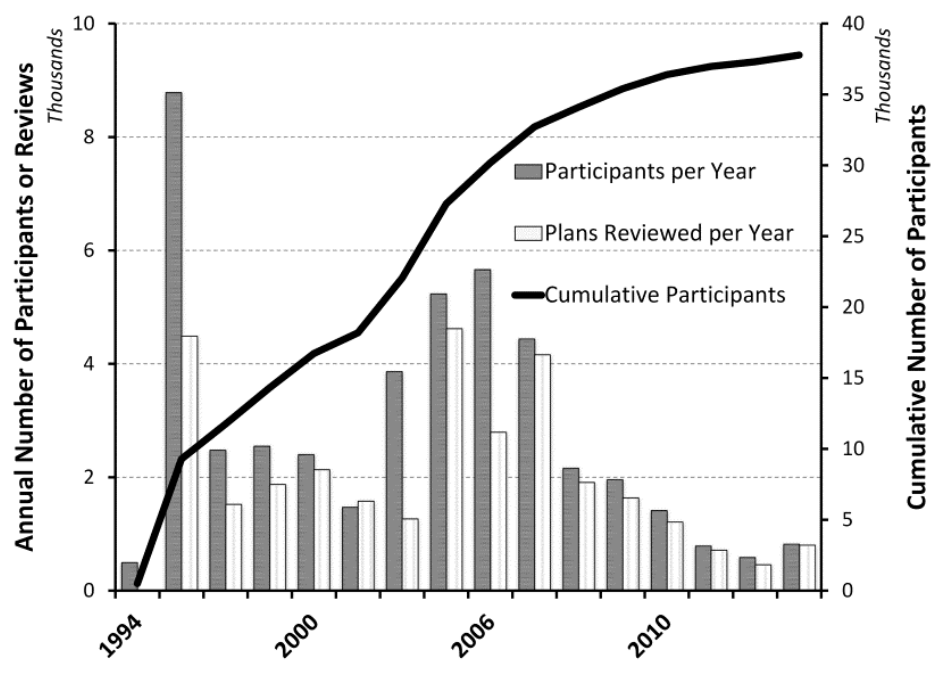

Figure 9. Annual and cumulative number of farmers participating in Environmental Farm Planning in Ontario and number of plans reviewed by a third party (1994-2013)

Cumulatively, 1994-2013, an estimated 37,800 Ontario farms - approximately 75\% of all farm businesses participated in the EFP program (Figure 9; Morrison \& FitzGibbon 2014). During 2005-2013, the federal-provincial Agricultural Policy Framework and then the Growing Forward agricultural policy framework initially provided an historic boost in funding to stewardship, and then a gradual reduction in funding (Morrison \& FitzGibbon 2014). A recent sample survey reported 38\% of Ontario farms had a current EFP, 72\% in Quebec (where it is a legal requirement), 53\% in the Atlantic provinces and lower in other provinces (Statistics Canada 2013d).

A 1999 sample survey of participating farmers found 54\% completion of actions identified in their EFPs (Summers et al., 2008; Plummer et al., 2007). In a follow up 2010 sample survey, 65\% of actions identified in EFPs were implemented (Prairie Research Associates, 2011). A 2006 national survey indicated more than 50\% of farms with EFPs had implemented all BMPs and about 45\% had partially implemented BMPs in their action plans in Ontario and Quebec (Agriculture and Agri-Food Canada, 2009).

During 2005-13, about 30\% of Ontario farms (over 15,000 farms) implemented over 23,400 projects assisted under cost sharing programs to implement nutrient management, riparian management, improved pest management, water well management or other environmental practices. The projects invested at least $\mathrm{C} \$ 350$ million including over C $\$ 225$ million from farmers. Analysis of the distribution of these projects shows the projects adopted addressed key risks of different types of farms in different regions (Woyzbun, 2012).

\section{Conclusions}

Agricultural land use and agri-environmental practices in any region are shaped by many factors, global, national and regional in scale, and ecological, economic, social, historical, policy and technological in focus. Trends in each region, like Ontario, reveal the unique set of influences that shape regional agriculture. As the case of Ontario shows, global influences such as modernization, specialization and "intensification" may be large drivers of regional trends, but particular regional drivers can create contrasting and sometimes surprising patterns.

Since 1826, historic colonial development shaped the early growth of Ontario agriculture and then the later $20^{\text {th }}$ century growth of agriculture in western Canada, which in turn changed Ontario agriculture. This historic pattern is similar in the US (Waisanen \& Bliss 2002). The shrinking total area occupied by Ontario farms is typical of land use transitions in many developed jurisdictions through the $20^{\text {th }}$ and $21^{\text {st }}$ centuries (Waisanen $\&$ Bliss 2002; Brown et al., 2005; Nickerson et al., 2011). This contrasts continued growth through the late $20^{\text {th }}$ century in western Canada. Ontario's relatively stable area of cropland is similar to mid-west US (Nickerson et al. 2011), but contrasts many parts of eastern and southern U.S. and Europe, where cropland continues to shrink in extent (Waisanen \& Bliss 2002; Ramankutty el al., 2010; Nickerson et al., 2011).

Long-term decreases in the number of cattle and area of hay and pasture have been transformative for Ontario, eastern Canada and even much of the US (Perlut, 2014). These decreases and related increases in western 
Canada, originate in changes in public policy supports for agriculture (Doan, Paddock \& Dyer 2006), relative costs of production and specialization (Veeman \& Gray 2010). Nevertheless, decreases in pasture and hay are typical of many developed countries (OECD 2008, 2013).

Agri-environmental stewardship, practice changes and long-term general reductions in phosphate fertilizer sales, pesticide volumes and manure volumes have led to general reductions in many agri-environmental risks in Ontario (Eilers et al., 2010), as they have in many developed countries (OECD 2008, 2013). Despite relative improvements, continuing and emerging concerns exist about agri-environmental risks include soil health, phosphorus management, water quality, habitat and pesticides. The relatively broad overview in this paper of trends in agriculture in Ontario, compared to the rest of Canada and other developed countries, provides a factual framework to inform priorities and decisions in agri-environmental policy in the 21 st century.

\section{Acknowledgements}

Thanks to Bill McGee, Kumuduni Kulasekera, Cindy Bradley-MacMillan, Bonnie Ball and Denise Beaton for access to data and discussion on analysis. Thanks to Ralph Martin, Robin MacKay, Pam Joosse, Kumuduni Kulasekera, David Cooper and Beverley Alder for reviewing the manuscript. Thanks to staff of Statistics Canada, Agriculture and Agri-Food Canada and Ontario Ministry of Agriculture, Food and Rural Affairs for the collection of vital information. Thanks to Ontario's farmers and their organizations for building stewardship initiatives.

\section{References}

Agriculture and Agri-Food Canada. (1997a). Profile of production trends and environmental issues in Canada's agriculture and agri-food sector. Publication 1938/E. Ottawa, Ontario: Agriculture and Agri-Food Canada.

Agriculture and Agri-Food Canada. (2009). Environmental Farm Planning in Canada: A 2006 Overview. Farm Environmental Management in Canada, Technical Series Report. Ottawa, Ontario. Agriculture and Agri-Food Canada, July, 2009.

Agriculture and Agri-Food Canada. (2011). An Overview of the Canadian Agriculture and Agri-Food System. Agriculture and Agri-Food Canada, Ottawa.

Beaulieu, M., \& Bédard, F. (2003). A geographic profile of Canadian livestock, 1991-2001. Agriculture and Rural Working Paper Series, Working Paper No. 62, Catalogue no. 21-601-MIE - No. 062. Statistics Canada, Ottawa.

Beaulieu, M., Fric, C., \& Soulard, F. (2007). Estimation of Water Use in Canadian Agriculture in 2001. Agriculture and Rural Working Paper Series, Statistics Canada, Ottawa, K1A 0T6. Catalogue no. 21-601-MIE - No. 087.

Blancher, P., Cadman, M., Pond, B., Couturier, A., Dunn, E., Francis, C., \& Rempel, R. (2007). Changes in Bird Distributions between Atlases, In M. Cadman, D. Sutherland, G. Beck, D. Lepage, \& A. Couturier (Eds.), Atlas of the Breeding Birds of Ontario, 2001-2005 (pp. 32-48). Bird Studies Canada, Environment Canada, Ontario Field Ornithologists, Ontario Ministry of Natural Resources, and Ontario Nature, Toronto, Canada.

Blann, K., Anderson, J., Sands, G., \& Vondracek, B. (2009). Effects of Agricultural Drainage on Aquatic Ecosystems: A Review. Critical Reviews in Environmental Science and Technology, 39, 909-1001. http://dx.doi.org/10.1080/10643380801977966

Brisson, Y. (2014). The changing face of the Canadian hog industry. Statistics Canada, Ottawa. Catalogue no. 96 $-325-\mathrm{X}-$ No. 005.

Brown, D., Johnson, K., Loveland, T., \& Theobald, D. (2005). Rural land-use trends in the conterminous United States, 1950-2000. Ecological Applications, 15, 1851-1863. http://dx.doi.org/10.1890/03-5220

Bucknell, D., \& Pearson, C. (2006). A spatial analysis of land-use change and agriculture in eastern Canada. $\begin{array}{llll}\text { International Journal of Agricultural Sustainability, } 4, & \text { 22-38. }\end{array}$ http://dx.doi.org/10.1080/14735903.2006.9686009

Bruulsema, T., Mullen, R., O’Halloran, I., \& Warncke, D. (2011). Agricultural phosphorus balance trends in Ontario, Michigan and Ohio. Canadian Journal of Soil Science, 91, 437-442. http://dx.doi.org/10.4141/cjss10002

Caldwell, W. (2001). A municipal perspective on risk management and agriculture. Great Lakes Geographer, 8, 32-40.

Chandler, R., \& Scott, M. (2011). Statistical methods for trend detection and analysis in the environmental 
sciences. Statistics in Practice Series, Wiley.

Chapra, S., \& Dolan, D. (2012). Great Lakes total phosphorus revisited: 2. Mass balance modelling. Journal of Great Lakes Research, 38, 741-754. http://dx.doi.org/10.1016/j.jglr.2012.10.002

de Loë, R. (2005). Agricultural Water Use: A Methodology and Estimates for Ontario (1991, 1996 and 2001). Canadian Water Resources Journal, 30, 111-128.

Derpsch, R., Friedrich, T., Kassam, A., \& Hongwen, L. (2010). Current status of adoption of no-till farming in the world and some of its main benefits. International Journal of Agricultural and Biological Engineering, 3, 1- 25. http://dx.doi.org/10.3965/j.issn.1934-6344.2010.01.0-0

Doan, D., Paddock, B., \& Dyer, J. (2006). The reform of grain transportation policy and transformation in western Canadian agriculture, In D. Blandford (Ed.), Policy Reform and Adjustment in the Agricultural Sectors of Developed Countries (pp. 163-173). Berkeley Hill.

Dolan, D., \& Chapra, S. (2012). Great Lakes total phosphorus revisited: 1. Loading analysis and update (19942008). Journal of Great Lakes Research, 38, 730-740. http://dx.doi.org/10.1016/j.jglr.2012.10.001

Dorff, E. (2014). The changing face of the Canadian fruit and vegetable sector: 1941 to 2011. Statistics Canada, Ottawa. Catalogue no. 96-325-X - No. 003.

Dorff, E., \& Beaulieu, M. (2014). Feeding the soil puts food on your plate. Statistics Canada, Ottawa. Catalogue no. 96-325-X - No. 004.

Drummond, M., \& Loveland, T. (2010). Land-use pressure and a transition to forest-cover loss in the eastern United States. BioScience, 60, 286-298. http://dx.doi.org/10.1525/bio.2010.60.4.7

Drury, C., Tan, C., Reynolds, W., Welacky, T., Oloya, T., \& Gaynor, J. (2009). Managing Tile Drainage, Subirrigation, and Nitrogen Fertilization to Enhance Crop Yields and Reduce Nitrate Loss. Journal of Environmental Quality, 38, 1193-1204. http://dx.doi.org/10.2134/jeq2008.0036

Ducks Unlimited. (2010). Southern Ontario wetland conversion analysis. Barrie, Ontario. Retrieved from http://www.ducks.ca/assets/2010/10/duc_ontariowca_optimized.pdf

Eastwood, R., Lipton, M., \& Newell, A. (2010). Farm size. In P. Pingali, \& R. Evenson (Eds.), Handbook of Agricultural Economics (Vol. 4, pp. 3323-3397). Elsevier.

Eilers, W., MacKay, R., Graham, L., \& Lefebvre, A. (Eds.) (2010). Environmental sustainability of Canadian agriculture. Agri-Environmental Indicator Report Series, Report \#3. Agriculture and Agri-Food Canada, 2010. Ottawa.

Elgåker, H. (2012). The new equine sector and its influence on multifunctional land use in peri-urban areas. GeoJournal, 77, 591-613. http://dx.doi.org/10.1007/s10708-010-9398-y

Environment Canada. (2013). National Inventory Report 1990-2011: Greenhouse gas sources and sinks in Canada. Ottawa, Canada.

Environment Canada. (2011). Presence and levels of priority pesticides in selected Canadian aquatic ecosystems. Ottawa, Canada.

Evans, V. (2011). Canadian equine industry profile study. Equine Canada, Ottawa. Retrieved September 23, 2013, from http://www.equinecanada.ca/industry/index.php?option=com_content\&view $=$ section\&id $=103 \&$ Itemid $=559 \&$ lang $=$ en

Ferreyra, C., de Loe, R., \& Kreutzwiser, R. (2008). Imagined communities, contested watersheds: Challenges to integrated water resources management in agricultural areas. Journal of Rural Studies, 24, 304-321. http://dx.doi.org/10.1016/j.jrurstud.2007.11.001

Gallivan, G., Surgeoner, G., \& Kovach, J. (2001). Pesticide risk reduction on crops in the province of Ontario. Journal of Environmental Quality, 30, 798-813.

Gouvernement du Québec. (2012). Bilan des ventes de pesticides au Québec pour l'année 2009. Ministère du Développement durable, de l'Environnement et des Parcs, Québec.

Government of Canada. (1935). Seventh Census of Canada, 1931, Ontario. Census of Agriculture. Dominion Bureau of Statistics, Ottawa.

Government of Ontario. (1998). Assessment Act, Ontario Regulation 282/98., Amended to O. Reg. 341/12. Retrieved April 15, 2013. 
Government of Ontario. (2003a). Nutrient Management Act, 2002, Ontario Regulation 267/03. Amended to O. Reg. 284/12. Retrieved April 15, 2013.

Government of Ontario. (2003b). Food Systems 2002: A program to reduce pesticides in food production. Ontario Ministry of Agriculture and Food, Guelph.

Government of Ontario. (2005a). Provincial policy statement. Ministry of Municipal Affairs and Housing, Toronto.

Government of Ontario. (2005b). The Greenbelt plan. Ministry of Municipal Affairs and Housing, Toronto.

Government of Ontario. (2006). Growth Plan for the Greater Golden Horseshoe. Ministry of Infrastructure, Toronto.

Government of Ontario. (2009). Agronomy guide for field crops. Publication 811. Ontario Ministry of Agriculture and Food, Guelph.

Grube, A., Donaldson, D., Kiely, T., \& Wu, L. (2011). Pesticides industry sales and usage, 2006 and 2007 market estimates. Office of Pesticide Programs, U.S. Environmental Protection Agency, Washington.

Hamel, M. A., \& Dorff, E. (2014). Corn: Canada's third most valuable crop. Catalogue no. 96-325-X - No. 002. Statistics Canada, Ottawa.

Hecky, R., Smith, R., Barton, D., Guildford, S., Taylor, W., Charlton, M., \& Howell, T. (2004). The nearshore phosphorus shunt: a consequence of ecosystem engineering by dreissenids in the Laurentian Great Lakes. Canadian Journal of Fisheries and Aquatic Sciences, 61, 1285-1293. http://dx.doi.org/10.1139/f04-065

Herath, D., Weersink, A., \& Carpentier, C. (2005). Spatial and temporal changes in the US hog, dairy, and fed-cattle sectors, 1975-2000. Applied Economic Perspectives and Policy, 27, 49-69. http://dx.doi.org/10.1111/j.1467-9353.2004.00207.x

Hiller, T., Powell, L., McCoy, T., \& Lusk, J. (2009). Long-term agricultural land-use trends in Nebraska, 18662007. Great Plains Research, 19, 225-237.

Hofmann, N., Filoso, G., \& Schofield, M. (2005). The loss of dependable agricultural land in Canada. Rural and Small Town Canada Analysis Bulletin, 6(1). Catalogue no. 21-006-XIE. Statistics Canada, Ottawa.

Hofmann, N. (2008). A geographical profile of livestock manure production in Canada, 2006. Catalogue no.16-002-X. Statistics Canada, Ottawa.

Hofmann, N., \& Kemp, L. (2001). A geographic profile of manure production in Canada. Catalogue no. 16-F0025-XIB. Statistics Canada, Ottawa.

Huffman, T., Ogston, R., Fisette, T., Daneshfar, B., Gasser, P-Y., White, L., Maloley, M., \& Chenier, R. (2006). Canadian agricultural land-use and land management data for Kyoto reporting. Canadian Journal of Soil Science, 86, 431-439.

Hume, D., \& Pearson, C. (2011). Transforming Farming Systems: Expanding the Production of Soybeans in Ontario. In P. Tow, I. Cooper, I. Partridge, \& C. Birch, (Eds.), Rainfed Farming Systems (pp. 791-803). Springer, Dordrecht, Netherlands.

Joseph, A., \& Keddie, P. (1981). The diffusion of grain corn production through southern Ontario, 1946-1971. Canadian Geographer, 25, 333-349.

Joosse, P., \& Baker, D. (2011). Context for re-evaluating agricultural source phosphorus loadings to the Great Lakes. Canadian Journal of Soil Science, 91, 317-327. http://dx.doi.org/10.4141/cjss10005

Kearney, J. (2010). Review: Food consumption trends and drivers. Philosophical Transactions of the Royal Society B 365, 2793-2807. http://dx.doi.org/10.1098/rstb.2010.0149

Keddie, P., \& Wandel, J. (2001). The "Second Wave": the expansion of soybeans across southern Ontario, 1951-96. Great Lakes Geographer, 8, 15-30.

Kelly, K. (1975). The artificial drainage of land in nineteenth-century southern Ontario. The Canadian Geographer, 19, 279-298. http://dx.doi.org/10.1111/j.1541-0064.1975.tb01869.x

Korol, M. (2002). Canadian fertilizer consumption, Shipments and Trade 2001/2002. Ottawa: Agriculture and Agri-Food Canada.

Krueger, R. (2000). Trials and tribulations of the Canadian fruit-growing industry. Canadian Geographer, 44, 342-354. http://dx.doi.org/10.1111/j.1541-0064.2000.tb00717.x 
Lambin, E., \& Meyfroidt, P. (2011). Global land use change, economic globalization, and the looming land scarcity. Proceedings of the National Academy of Sciences, 108, 3465-3472. http://dx.doi.org/10.1073/pnas.1100480108

Lambin, E., \& Meyfroidt, P. (2010). Land use transitions: Socio-ecological feedback versus socio-economic change. Land Use Policy, 27, 108-118. http://dx.doi.org/10.1016/j.landusepol.2009.09.003

Larson, B., Riley, J., Snell, E., \& Godschalk, H. (1999). The woodland heritage of Southern Ontario. A study of ecological change, distribution and significance. Federation of Ontario Naturalists, Toronto.

Lobb, D., Huffman, E., \& Reicosky, D. (2007). Importance of information on tillage practices in the modelling of environmental processes and in the use of environmental indicators. Journal of Environmental Management, 82, 377-387. http://dx.doi.org/10.1016/j.jenvman.2006.04.019

Loftus, K., Smardon, R., \& Potter, B. (2004). Strategies for the stewardship and conservation of Great Lakes coastal wetlands. Aquatic Ecosystem Health, 7, 305-330. http://dx.doi.org/10.1080/14634980490462154

MacDonald, G., \& Bennett, E. (2009). Phosphorus accumulation in Saint Lawrence River watershed soils: A century-long perspective. Ecosystems, 12, 621-635. http://dx.doi.org/10.1007/s10021-009-9246-4

Madramootoo, C., \& Johnston, W. (2007). Agricultural drainage management, quality and disposal issues in North America. Irrigation and Drainage, 56, S35-S45. http://dx.doi.org/10.1002/ird.343

McCuaig, J., \& Manning, E. (1982). Agricultural land use change in Canada: process and consequences. Environment Canada, Catalogue 73-1/21E, Ottawa.

McGee, B., Berges, H., \& Beaton, D. (2010). Survey of pesticide use in Ontario, 2008, Estimates of pesticides used on field crops, fruit and vegetable crops, and other agricultural crops. Ontario Ministry of Agriculture, Food and Rural Affairs, Guelph.

McInnis, P. (2010). Pesticides in Ontario's treated municipal drinking water 1986-2006. Ontario Ministry of the Environment, Toronto.

McKeown, A., Warland, J., \& McDonald, M. (2005). Long-term marketable yields of horticultural crops in southern Ontario in relation to seasonal climate. Canadian Journal of Plant Sciences, 85, 431-438. http://dx.doi.org/10.4141/P03-223

McCracken, J. (2005). Where the Bobolinks roam: the plight of North America's grassland birds. Biodiversity, 6 , 20-29. http://dx.doi.org/10.1080/14888386.2005.9712771

Meyfroidt, P., \& Lambin, E. (2011). Global Forest Transition: Prospects for an End to Deforestation. Annual Review of Environment and Resources, 36, 343-71. http://dx.doi.org/10.1146/annurev-environ-090710-143732

Milburn, L. (2011). The new decision-makers in the rural landscape - who are non-farm rural landowners? Journal of Rural Community Development, 6, 1-21.

Morris, C., \& Evans, N. (2004). Agricultural turns, geographical turns: retrospect and prospect. Journal of Rural Studies, 20, 95-111. http://dx.doi.org/10.1016/S0743-0167(03)00041-X

Morrison, K., \& FitzGibbon, J. (2014). Adaptive governance of dynamic social-ecological systems: the case of the Ontario Environmental Farm Plan (1992-2011). Agroecology and Sustainable Food Systems, 38, 378-409. http://dx.doi.org/10.1080/21683565.2013.870627

Morrison, M., Voldeng, H., \& Cober, E. (2000). Agronomic changes from 58 years of genetic improvement of short-season soybean cultivars in Canada. Agronomy Journal, 92, 780-784. http://dx.doi.org/10.2134/agronj2000.924780x

Nickerson, C., Ebel, R., Borchers, A., \& Carriazo, F. (2011). Major uses of land in the United States, 2007. United States Department of Agriculture, Economic Research Service, Economic Information Bulletin Number 89, Washington.

Ontario Farm Environment Coalition (OFEC) (1992). Our farm environmental agenda. Toronto.

Organisation for Economic Co-operation and Development (OECD) (2013). OECD Compendium of Agri-environmental Indicators. OECD, Paris. http://dx.doi.org/10.1787/9789264181151-en

Organisation for Economic Co-operation and Development (OECD). (2008). Environmental performance of agriculture in OECD countries since 1990. OECD, Paris. 
Osteen, C., \& Fernandez, C. J. (2013). Economic and policy issues of U.S agricultural pesticide use trends. Pest Management Science, 69, 1001-1025. http://dx.doi.org/10.1002/ps.3529

Papadopoulos, A., \& Gosselin, A. (2007). Greenhouse vegetable production in Canada. Chronica Horticulturae, 47, 23-28.

Pawlick, T. (2001). The invisible farm: the worldwide decline of farm news and agricultural journalism training. Burnham, Chicago.

Perlut, N. (2014). Grassland birds and dairy farms in the northeastern United States. Wildlife Society Bulletin, 38, 574-579. http://dx.doi.org/10.1002/wsb.415

Plummer, R., Speirs, A., Summer, R., \& FitzGibbon, J. (2007). The contributors of stewardship to managing agro-ecosystem environments. Journal of Sustainable Agriculture, 31, 55-84. http://dx.doi.org/10.1300/J064v31n03_06

Pond, D. (2009). Ontario's Greenbelt: Growth management, farmland protection, and regime change in southern Ontario. Canadian Public Policy, 35, 413-432. http://dx.doi.org/10.3138/cpp.35.4.413

Pongratz, J., Reick, C., Raddatz, T., \& Claussen, M. (2008). A reconstruction of global agricultural areas and land cover for the last millennium. Global Biogeochemical Cycles, 22, 3018-3153. http://dx.doi.org/10.1029/2007GB003153

Prairie Research Associates. (2011). Environmental Farm Plans: measuring performance, improving effectiveness, and increasing participation. Retrieved from http://stewardshipnetwork.ca/files/2012/07/Final-Report-EFPs-Measuring-Performance-Improving-Effectiv eness-and-Increasing-Participation.pdf

Rajsic, P., Ramlal, E., Fox, G., \& Brouwer, F. (2012). Canadian agricultural environmental policy: from the right to farm to farming right. In F. Brouwer, G. Fox, \& R. Jongeneel (Eds.), The Economics of Regulation in Agriculture: Compliance with Public and Private Standard. CABI, Wallingford, UK.

Ramankutty, N., Heller, E., \& Rhemtulla, J. (2010). Prevailing myths about agricultural abandonment and forest regrowth in the United States. Annals of the Association of American Geographers, 100, 502-512. http://dx.doi.org/10.1080/00045601003788876

Rudela, T., Coomes, O., Moran, E., Achard, F., Angelsen, A., Xu, J., \& Lambin, E. (2005). Forest transitions: towards a global understanding of land use change. Global Environmental Change, 15, 23-31. http://dx.doi.org/10.1016/j.gloenvcha.2004.11.001

Salmi, T., Määttä, A., Anttila, P., Ruoho-Airola, T., Amnell, T., \& Laitos, I. (2002). Detecting trends of annual values of atmospheric pollutants by the Mann-Kendall test and Sen's slope estimates -the excel template application MAKESENS. Publications on air quality No. 31. Meteorologiska Institutet, Finnish Meteorological Institute, Helsinki.

Sargeant, J., Leslie, K., Shoukri, M., Martin, S., \& Lissemore, K. (1998). Trends in milk component production in dairy herds in Ontario: 1985-1994. Canadian Journal of Animal Science, 78, 413-420.

Senate of Canada. (1984). Soil at Risk, Canada's Eroding Future. Ottawa.

Shear, H. (2006). The Great Lakes, an ecosystem rehabilitated, but still under threat. Environmental Monitoring and Assessment, 13, 199-225. http://dx.doi.org/10.1007/s10661-005-9081-9

Schulte, H. B., Walters, D., Powell, C., \& Shrubsole, D. (2007). Wetland management: An analysis of past practice and recent policy changes in Ontario. Journal of Environmental Management, 82, 83-94. http://dx.doi.org/10.1016/j.jenvman.2005.12.007

Small, E. (1999). New crops for Canadian agriculture. In J. Janick (Ed.), Perspectives on New Crops and New Uses. Proceedings of the Fourth National Symposium New Crops and New Uses: Biodiversity and Agricultural Sustainability. ASHS Press, Alexandria, VA.

Statistics Canada. (2007). Selected historical data from the census of agriculture. Publication 95-632-XWE. Statistics Canada, Ottawa. Retrieved from http://www.statcan.gc.ca/pub/95-632-x/95-632-x2007000-eng.htm

Statistics Canada. (2008). 2006 Census of agriculture. Statistics Canada, Ottawa.

Statistics Canada. (2012a). 2011 Census of Agriculture. Statistics Canada, Ottawa.

Statistics Canada. (2012b). Fruit and vegetable production. Catalogue no. 22-003-X. Statistics Canada, Ottawa. 
Statistics Canada. (2013a). Census of agriculture, total area of farms and use of farm land, Canada and provinces 1921-2011. CANSIM Table 004-0002. Statistics Canada, Ottawa.

Statistics Canada. (2013b). Fertilizer shipments to Canadian agriculture markets, by nutrient content and fertilizer year, annual. CANSIM Table 001-0065. Statistics Canada, Ottawa.

Statistics Canada. (2013c). Table 004-0004 Census of Agriculture, selected livestock and poultry data, Canada and provinces, every 5 years 1921-2011. CANSIM Table 004-0004. Statistics Canada, Ottawa.

Statistics Canada. (2013d). Farm Environmental Management Survey 2011. Catalogue no. 22-003-X. Statistics Canada, Ottawa.

Stonehouse, D., \& Bohl, M. (1990). Land degradation issues in Canadian agriculture. Canadian Public Policy, $16,418-431$.

Summers, R., Plummer, R., \& FitzGibbon, J. (2008). Accounting precautionary measures in agriculture through pathway analysis: The case of the Environmental Farm Plan. International Journal of Agriculture, Resources, Governance and Ecology, 7, 437-449. http://dx.doi.org/10.1504/IJARGE.2008.022746

Thornton, P. (2010). Livestock production: recent trends, future prospects. Philosophical Transactions of the Royal Society B, 365, 2853-2867. doi:10.1098/rstb.2010.0134

Trant, G. (1983). Agriculture. In Historical Statistics of Canada. Publication 11-516-X, Statistics Canada, Ottawa. Retrieved from http://www.statcan.gc.ca/pub/11-516-x/sectionm/4057754-eng.htm

Unc, A., \& Goss, M. (2004). Transport of bacteria from manure and protection of water resources. Applied Soil Ecology, 25, 1-18.

USDA Economic Research Service. (2012). Fertilizer Consumption and Use-Table 1-U.S. consumption of nitrogen, phosphate, and potash, 1960-2009. Retrieved May 1, 2012, from http://www.ers.usda.gov/data-products/fertilizer-use-and-price.aspx

Uri, N. (1999). The use of no till farming in U.S. agriculture: farmers' perceptions versus reality. Journal of Sustainable Agriculture, 15, 2-3, 5-17. http://dx.doi.org/10.1300/J064v15n02_03

Valipour, M. (2014). Future of agricultural water management in Americas. Journal of Agricultural Research, 52, 245-267.

Valipour, M. (2013). Necessity of Irrigated and Rainfed Agriculture in the World. Irrigation and Drainage Systems Engineering S9: e001. http://dx.doi.org/10.4172/2168-9768. S9-e001

Valipour, M., Ahmadi, M., Raeini, S. M., Sefidkouhi, M., Shahnazari, A., Fazlola, R., \& Darzi, N. A. (2015). Agricultural water management in the world during past half century. Archives of Agronomy and Soil Science, 61(5), 657-678. http://dx.doi.org/10.1080/03650340.2014.944903

van Bochove, E., Denault, J. T., Leclerc, M. L., Theriault, G., Dechmi, F., Allaire, S., Rousseau, A., \& Drury, C. (2011). Temporal trends of risk of water contamination by phosphorus from agricultural land in the Great Lakes watersheds of Canada. Canadian Journal of Soil Science, 91, 443-453. http://dx.doi.org/10.4141/cjss09122

Van Vliet, L., Macintosh, E., \& Hoffman, D. (1979). Effects of land capability on apple production in Southern Ontario. Canadian Journal of Soil Science, 59,163-175. http://dx.doi.org/10.4141/cjss79-016

Veeman, T., \& Gray, R. (2010). The shifting patterns of agricultural production and productivity in Canada. In J. Alston, B. Babcock, \& P. Pardey, (Eds.), The Shifting Patterns of Agricultural Production and Productivity Worldwide (pp. 123-147). Iowa State University, Ames, Iowa.

Venterea, R., Halvorson, A., Kitchen, N., Liebig, M., Cavigelli, M., Del Grosso, S., ... Collins, H. (2012). Challenges and opportunities for mitigating nitrous oxide emissions from fertilized cropping systems. Frontiers of Ecology and Environment, 10, 562-570. http://dx.doi.org/10.1890/120062

Waisanen, P., \& Bliss, N. (2002). Changes in population and agricultural land in conterminous United States counties, 1790 to 1997. Global Biogeochemical Cycles, 16, 84-1-84-19. http://dx.doi.org/10.1029/2001GB001843, 2002.

Walters, D., \& Shrubsole, D. (2005). Assessing efforts to mitigate the impacts of drainage on wetlands in Ontario, Canada. The Canadian Geographer, 49(2), 155-171. http://dx.doi.org/10.1111/j.0008-3658.2005.00086.x

Watelet, A. (2009). Emprise et déprise de l'agriculture sur le territoire de l'est de l'Ontario de 1826 à 2006: la dimension environnementale.

Canadian

Geographer,

53 ,

45-62. 
http://dx.doi.org/10.1111/j.1541-0064.2009.00236.x

Wilton, B., \& Caldwell, W. (2009). Rural Ontario's 'hidden' sector: the economic importance of the horse industry final report - 2009. University of Guelph, Guelph, ON. Retrieved September 23, 2013, from http://www.waynecaldwell.ca/Projects/horsefarms/Final\%20Report\%20-\%202009.pdf

Wolter, P., Johnston, C., \& Niemi, G. (2006). Land use land cover change in the U.S. Great Lakes basin 1992 to 2001. Journal of Great Lakes Research, 32, 607-628. http://dx.doi.org/10.3394/0380-1330(2006)32[607:LULCCI]2.0.CO;2

Woyzbun, E. (2012). Spatial analysis of the adoption of nutrient management related best management practices in Ontario, April 2005 - March 2010. Agriculture and Agri-Food Canada, Guelph. Retrieved from http://www.ontariosoilcrop.org/docs/final_report_spatial_analysis_nm_bmp_ontario.pdf

Yang, X., Drury, C., \& Wander, M. (2013). A wide view of no-tillage practices and soil organic carbon sequestration. Acta Agriculturae Scandinavica, Section B - Soil and Plant Science, 63, 523-530. http://dx.doi.org/10.1080/09064710.2013.816363

Yates, A., Bailey, R., \& Schwindt, J. (2006). No-till cultivation improves stream ecosystem quality. Journal of Soil and Water Conservation, 61, 114-19.

Yue, S., Pilon, P., \& Cavadias, G. (2002). Power of the Mann-Kendall and Spearman's rho tests for detecting monotonic trends in hydrological series. Journal of Hydrology, 259, 254-271. http://dx.doi.org/10.1016/S0022-1694(01)00594-7

\section{Copyrights}

Copyright for this article is retained by the author(s), with first publication rights granted to the journal.

This is an open-access article distributed under the terms and conditions of the Creative Commons Attribution license (http://creativecommons.org/licenses/by/3.0/). 